\title{
Palynology of the Permian succession of Spitsbergen, Svalbard
}

\author{
G. MANGERUD and R. M. KONIECZNY
}

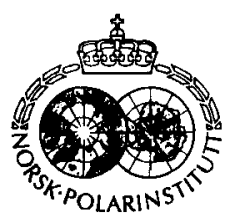

\begin{abstract}
Mangerud, G. \& Konieczny, R. M. 1993: Palynology of the Permian succession of Spitsbergen, Svalbard. Polar Research 12 (1), 65-93.

Palynological investigations of 16 sections from Spitsbergen, Svalbard, covering the uppermost Carboniferous, Permian and lowermost Triassic succession have been carried out. Because of general poor preservation and barrenness of the majority of the samples, it was not possible to establish a formal zonation for the Permian succession. The study resulted, however, in the recognition of three Permian palynological assemblages, restricted downwards by a Carboniferous assemblage and upwards by an earliest Triassic (Griesbachian) assemblage. The dating of these assemblages is based on palynological correlation with similar palynofloras elsewhere in the present Arctic region as well as dating by marine faunas, which in general give better stratigraphic resolution. The Permian assemblages recognised include (1) the Vittatina assemblage of late Gzhelian to early Asselian age recorded in the lower parts of the Tyrrellfjellet Member (Nordenskiöldbreen Formation), (2) the Hamiapollenites tractiferinus assemblage of late Asselian to Artinskian age recorded in the upper parts of the Tyrrellfjellet Member and in the Gipshuken Formation and (3) the youngest Permian Kraeuselisporites assemblage of late Artinskian to ?earliest Tatarian age recorded in the Kapp Starostin Formation.
\end{abstract}

G. Mangerud and R. M. Konieczny*, IKU Petroleum Research, N-7034 Trondheim, Norway

\section{Introduction}

Permian lithostratigraphy of Spitsbergen, Svalbard, was described by Cutbill \& Challinor (1965), who also presented data on fusulinid zonation. Several papers concerning various fossil groups have been published subsequently, including Sosipatrova (1967), Ustritskii $(1967,1979)$, Czarniecki (1969), Federowski (1967, 1986), Szaniawski \& Malkowski (1979), Morozova \& Kruchinina (1986), Nakamura et al. $(1987,1992)$, Nakrem (1991a, b), Sakagami (1992), Ezaki \& Kawamura (1992) and Igo \& Okimura (1992). Except for one paper dealing with the palynology of Nordaustlandet (Mangerud \& Konieczny 1991) and one paper giving a general overview of the biostratigraphy of the Permian succession of Svalbard (Nakrem et al. 1992), no work has been published on the palynology of the Permian in this region.

For several years IKU Petroleum Research carried out work in Svalbard through the IKU Arctic Geoprogram. The disciplines involved included sedimentology, organic geochemistry and paleontology. The material on which the present

\footnotetext{
* Present address: Norwegian Institute for Water Research (NIVA), P.O. Box 69 Korsuoll, N-0808 Oslo 8, Norway.
}

study is based was collected by R. M. Konieczny in 1985 and 1986.

The purpose of this paper is to present palynological data and age discussions for the Permian succession of Spitsbergen based on several outcrop sections, mainly from the Isfjorden area (Fig. 1). Due to few productive samples and the generally poor preservation of the palynomorphs, no formal zonation has been established on Spitsbergen. From the Barents Shelf, however, wellpreserved assemblages have proven valuable in dating the Permian succession (IKU in-house data).

\section{Geological framework}

On Spitsbergen, the main island of the Svalbard archipelago, Permian rocks are exposed in an area around Isfjorden, along the Tertiary foldbelt on the western coast and in the Lomfjord area on the north-eastern coast (Fig. 1). The Carboniferous and Permian lithostratigraphy published by Cutbill \& Challinor (1965) divides the Permian into three formations in the study area (Fig. 2): The Nordenskiöldbreen Formation (Middle Carboniferous to Lower Permian), the Gipshuken Formation (Lower Permian), and the 


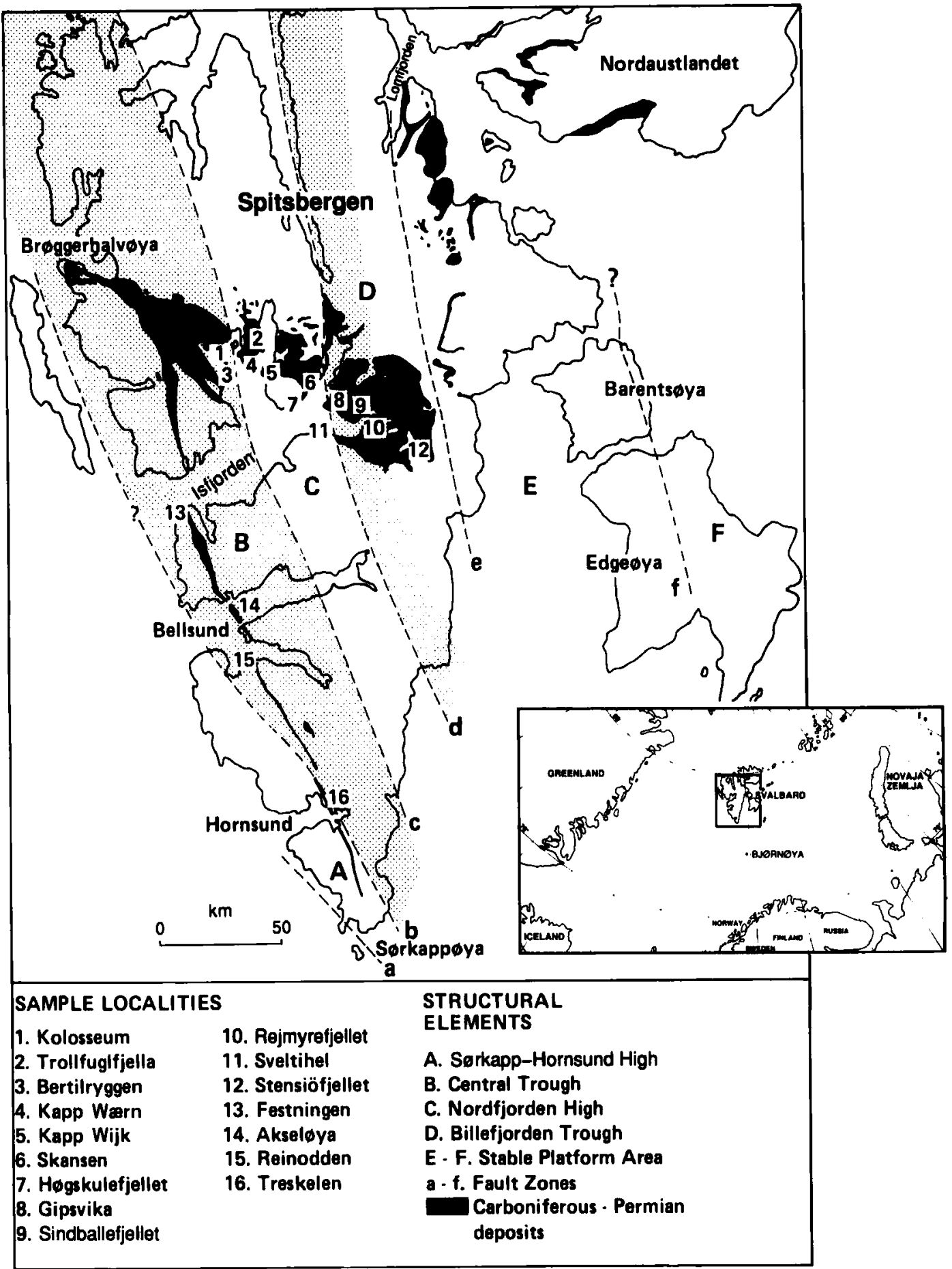

Fig. 1. Regional map of the central part of the Svalbard archipelago showing Carboniferous-Permian outcrops and sample localities. Base map from Steel \& Worsley (1984). 
Fig. 2. Stratigraphic scheme for the Permian succession of Spitsbergen, Svalbard, including the position of the described palynological assemblages. Ages based on Harland et al. (1989).

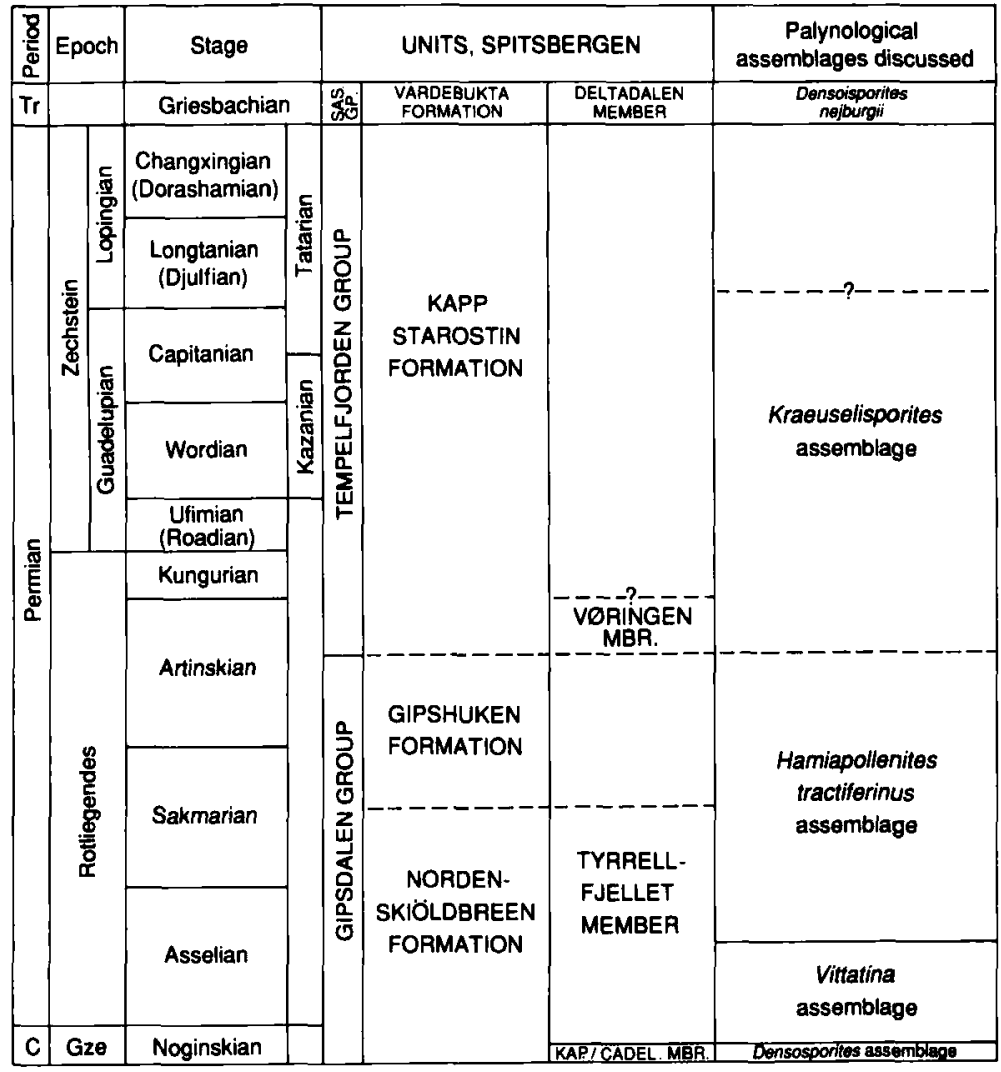

Kapp Starostin Formation (upper Lower Permian to Upper Permian).

During the Late Paleozoic, the Svalbard Platform was part of a sedimentary basin covering most of the present day Barents Shelf. It was also connected westward to North Greenland and the Sverdrup Basin in the Canadian Arctic, and eastward to the Timan Pechora Basin in Russia. During the Carboniferous, sedimentation was controlled by the Nordfjorden High (Fig. 1) giving rise to a distinct block-and-basinal deposition on Spitsbergen. The Nordfjorden High acted as a barrier until it was transgressed during the latest Carboniferous/earliest Permian time period. More open marine conditions were gradually established during the period Asselian to Artinskian, as seen in this carbonate dominated succession. Gypsum/anhydrite units reflect the arid climate during this period (Steel \& Worsley 1984). Shoals and bioherms seem to have been developed mainly along the earlier blocks, although no significant thickness variation can be seen in the
Lower Permian succession (Steel \& Worsley 1984). A regressive trend is reflected in the lower parts of the Gipshuken Formation with sabkhas developing eastwards to the eastern margin of the Nordfjorden High (Steel \& Worsley 1984). In the upper parts a more open marine environment is recognised (Keilen 1992).

Sometime during the mid-Permian the general northwards drift led to a colder climate in the area, and carbonate deposition gradually decreased. Transition to stable platform environment was accompanied by a major transgression establishing new seaways also down to East Greenland (Doré 1991). No evidence of syn-sedimentary faulting is seen in the upper Permian succession on central Spitsbergen, while to the southwest the Sørkapp-Hornsund High (Fig. 1) acts as a positive structure. The basal bioclastic limestone (Vøringen Member) of the Kapp Starostin Formation deposited in central parts of Spitsbergen represents shoreface deposits. These were formed by the transgression that took place 


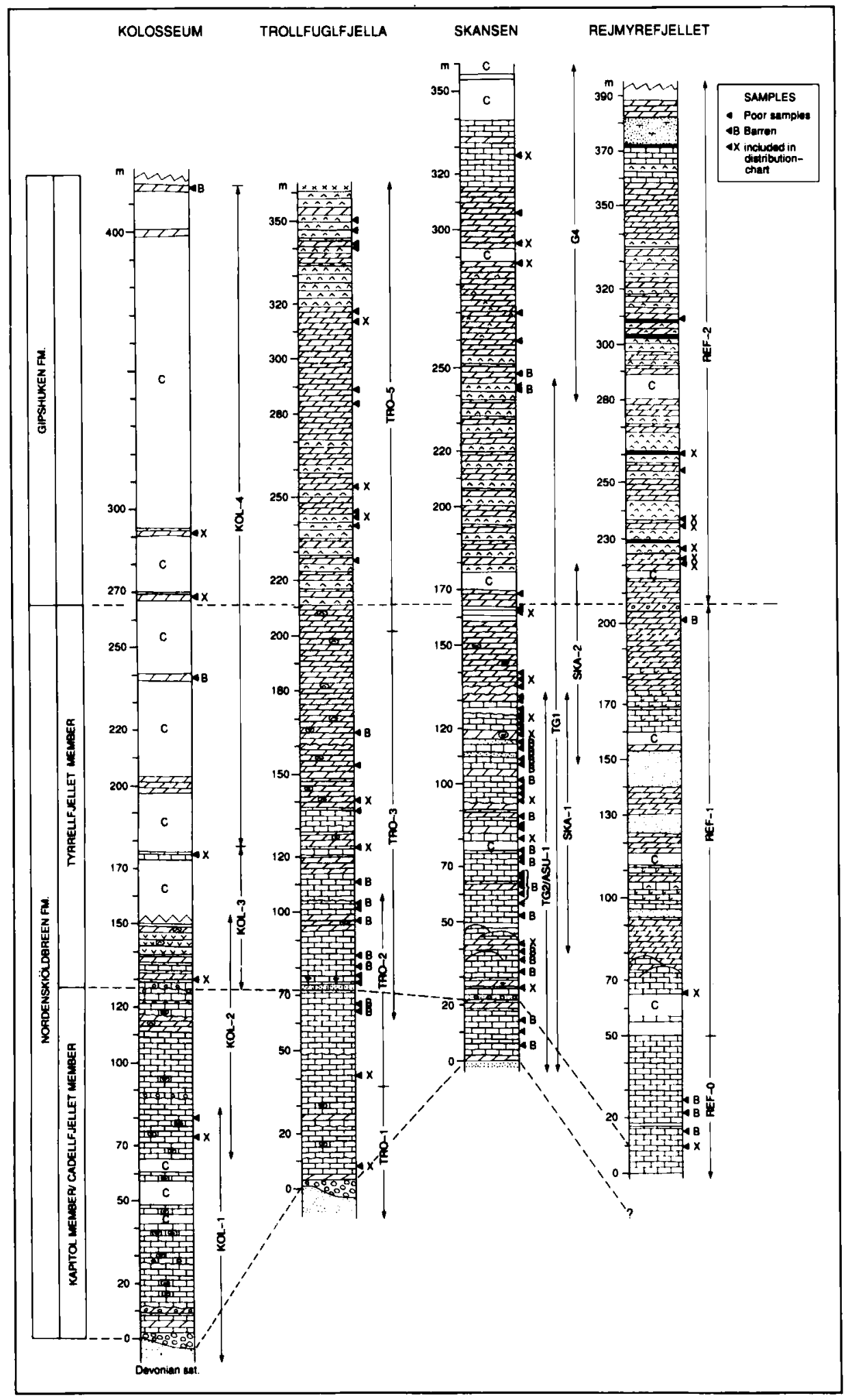


across the restricted marine platform represented by the underlying Gipshuken Formation strata (Steel \& Worsley 1984). There is a gradual development into the siliceous shales and siltstones derived from sponge spicules, which form the most characteristic feature of the Kapp Starostin Formation. Abundant trace fossils such as Zoophycus indicate low energy, but oxygenated, bottom environments, while organic sponge buildups are concentrated along the platform margins (Steel \& Worsley 1984). In the Late Permian a cold water fauna replaced the Early Permian warm water fauna in the Spitsbergen area (Keilen 1992), contemporaneous with a change to a temperate, humid climate that persisted as the entire platform moved northwards during the Mesozoic.

\section{Material}

Palynological samples were collected from 16 sections, 4 sections (13-16, Fig. 1) in the western fold belt and 12 sections (1-12, Fig. 1) located in the inner Isfjorden area. Maps showing the localisation of the different composite sections are given in the Appendix. A total of 340 samples were analysed, approximately 65 from the Nordenskiöldbreen Formation, 50 from the Gips-

\begin{tabular}{|c|c|c|}
\hline \multicolumn{3}{|l|}{ LEGEND } \\
\hline Sandstone & 樫空 & Evaporitic limestone \\
\hline 国 Shale/ claystone & 届重 & Bioherm \\
\hline 臣 Limestone & $\begin{array}{ll}-1 \\
-1 \\
-1\end{array}$ & Calcite cement \\
\hline F Dolomite & +2 & Dolomite cement \\
\hline 000 Conglomerate & Q & Limestone nodule \\
\hline Evaporite & (ㄴ) & Calcite nodule \\
\hline $\left.\begin{array}{|lll}x & x & x \\
x & x\end{array}\right]$ Dolerite & (4) & Dolomite nodule \\
\hline 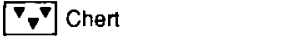 & 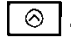 & Anhydrite nodule \\
\hline Sandy limestone & $\theta$ & Chert nodule \\
\hline Dolomite limestone & $m$ & Erosive contact \\
\hline 空国 Cherty timestone & $\mathrm{c}$ & Covered \\
\hline
\end{tabular}

Fig. 3. Lithological columns for the investigated sections of the Nordenskiöldbreen and Gipshuken Formations on Spitsbergen. The simplified logs are based on Dons (1983) (Kolosseum and Trollfuglfjella), Skaug (1982) (Skansen) and unpublished fieldlogs and sample descriptions by Konieczny. Palynological sample levels are indicated. huken Formation and 225 from the Kapp Starostin Formation. The samples were given standard palynological treatment, and a large number proved to be barren. The preservation of the palynomorphs is in general poor. The palynomorphs are thin-walled, corroded and often folded, a phenomenon commonly seen in carbonate and evaporite sequences. The palynomorphs do not show much sign of pyrite growth, not even in samples from the deeper basinal facies within the upper part of the Kapp Starostin Formation. They seem to be extensively oxidised, but are in general not highly mature. Maturity indexes fall within the oil window, giving TAI values (on a fire-scale) between $2+$ and 3 in the Isfjorden area, and around 4 in the southwestern area. It is therefore difficult to evaluate why the preservation is so poor in the low maturity area and why a majority of the horizons are barren. The poor preservation in the highly silicified shales developed from sponge spicules in the Kapp Starostin Formation can be related to oxidation or perhaps microbial degradation in this depositional environment.

Lithological logs (Figs. 3 and 4 ) and distribution charts (Figs. 5-10) are included from all localities except the Gipsvika, Sindballefjellet, Reinodden and Treskelen localities, which were found to be nearly barren throughout. Semiquantitative results are given as percentages of the total assemblage and are based on counts of 200 specimens where this was possible. Only samples with more than 100 specimens are included (Fig. 11). Frequences of each taxa are expressed as rare $(<5 \%)$, common $(5-10 \%)$ and abundant $(>10 \%)$ on the legend added to each distribution chart. Lithological logs are simplified from the unpublished field-logs of Hellem (1980) (Festningen, Høgskulefjellet, Kapp Wijk, Kapp Wærn and Stensiöfjellet), Skaug (1982) (Skansen) and Dons (1983) (Kolosseum and Trollfuglfjella). With the exception of the Festningen and Akseløya localities, all distribution charts represent composites of two or three closely spaced sections giving the range through the Permian succession of each area. An alphabetical list of species is included (Table 1). To demonstrate the diversity, the best preserved specimens are illustrated (Figs. 12-17), but these are not typical for this material with regard to the quality of preservation. The palynological slides are housed in the type collection of the Paleontological Museum, Oslo, under the numbers PMO 139.075-139.096. 


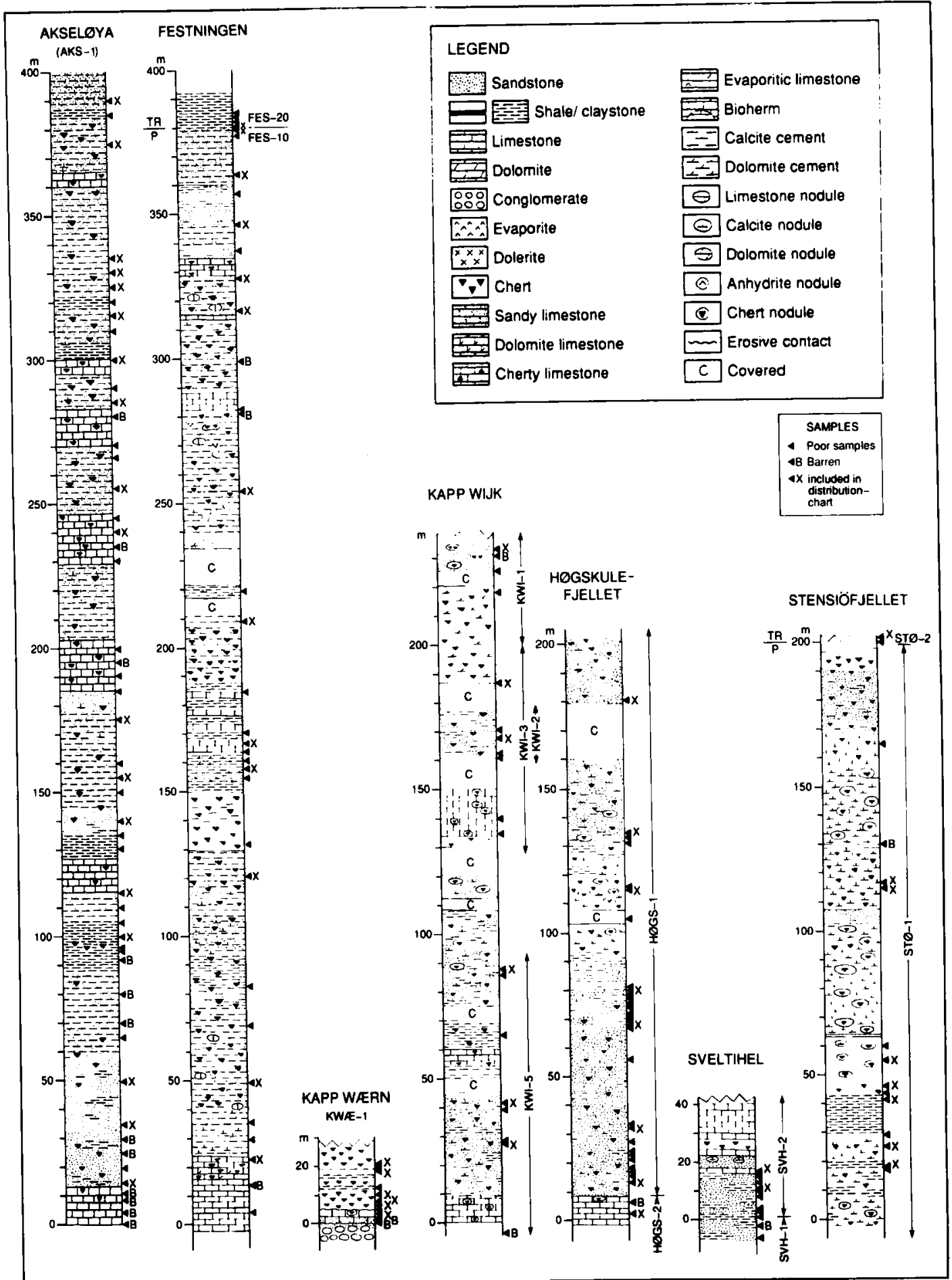

Fig. 4. Lithological columns for the investigated sections of the Kapp Starostin Formation on Spitsbergen. The simplified logs are based on Hellem (1980) (Festningen, Høgskulefjellet, Kapp Wijk, Kapp Warn and Stensiöfjellet) and unpublished field-logs by Konieczny. Palynological sample levels are shown. 


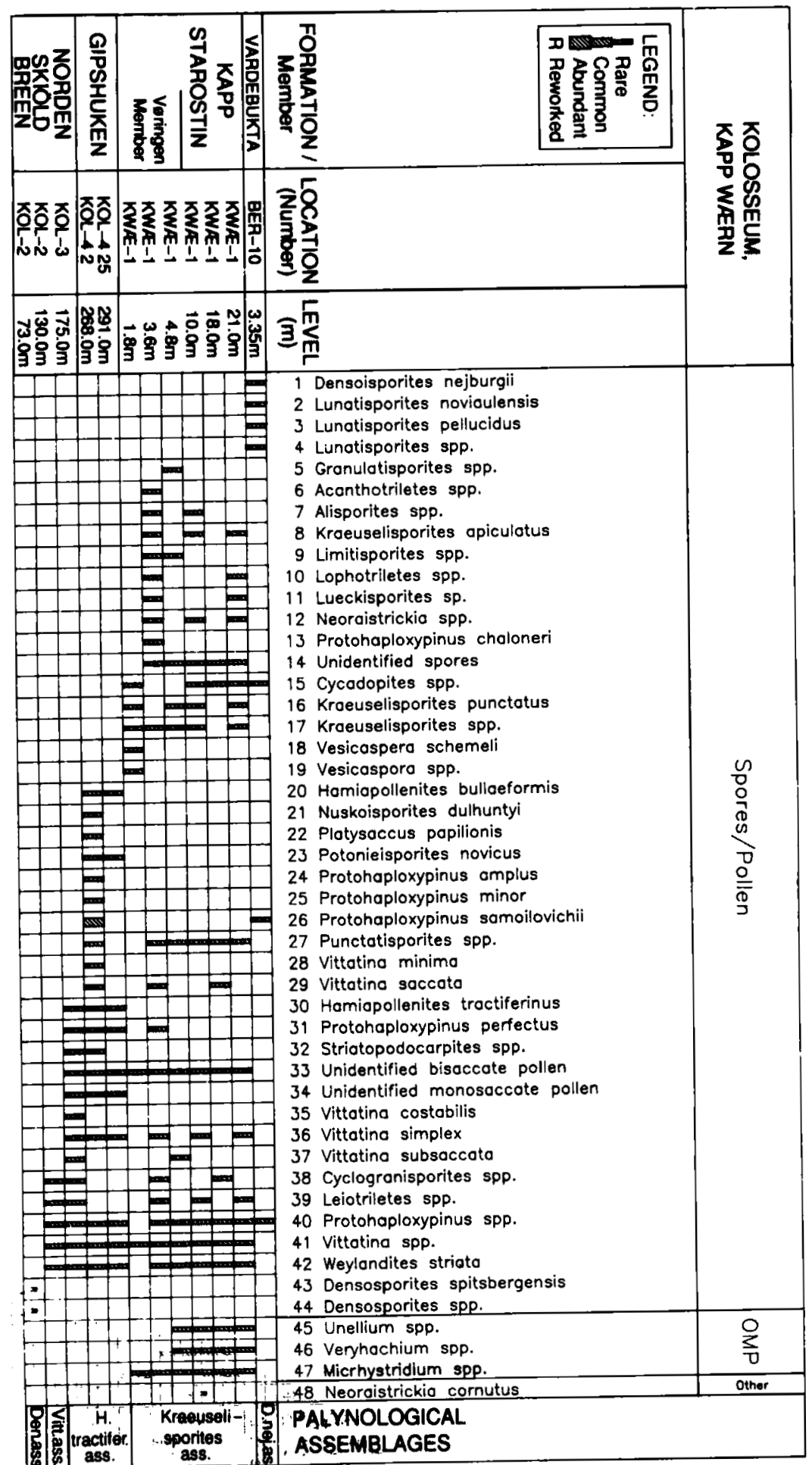

Fig. 5. Distribution chart for the Kolosseum and Kapp Warn lopalities, representing the Permian succession of West-Mid Central Spitsbergen. 


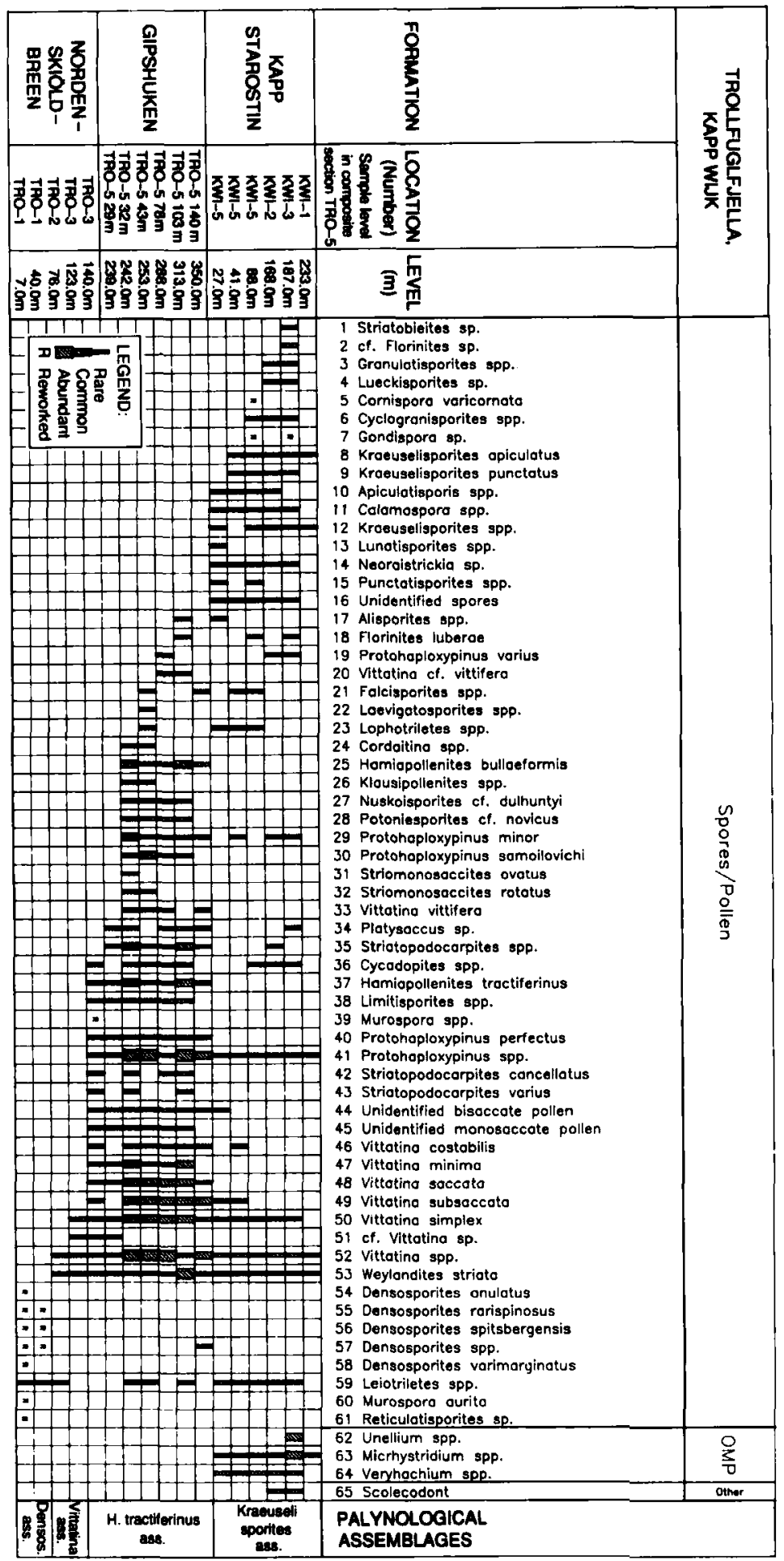

Fig. 6. Distribution chart for the Trollfuglfjella and Kapp Wijk localities, representing the Permian succession of Mid-Central Spitsbergen. 


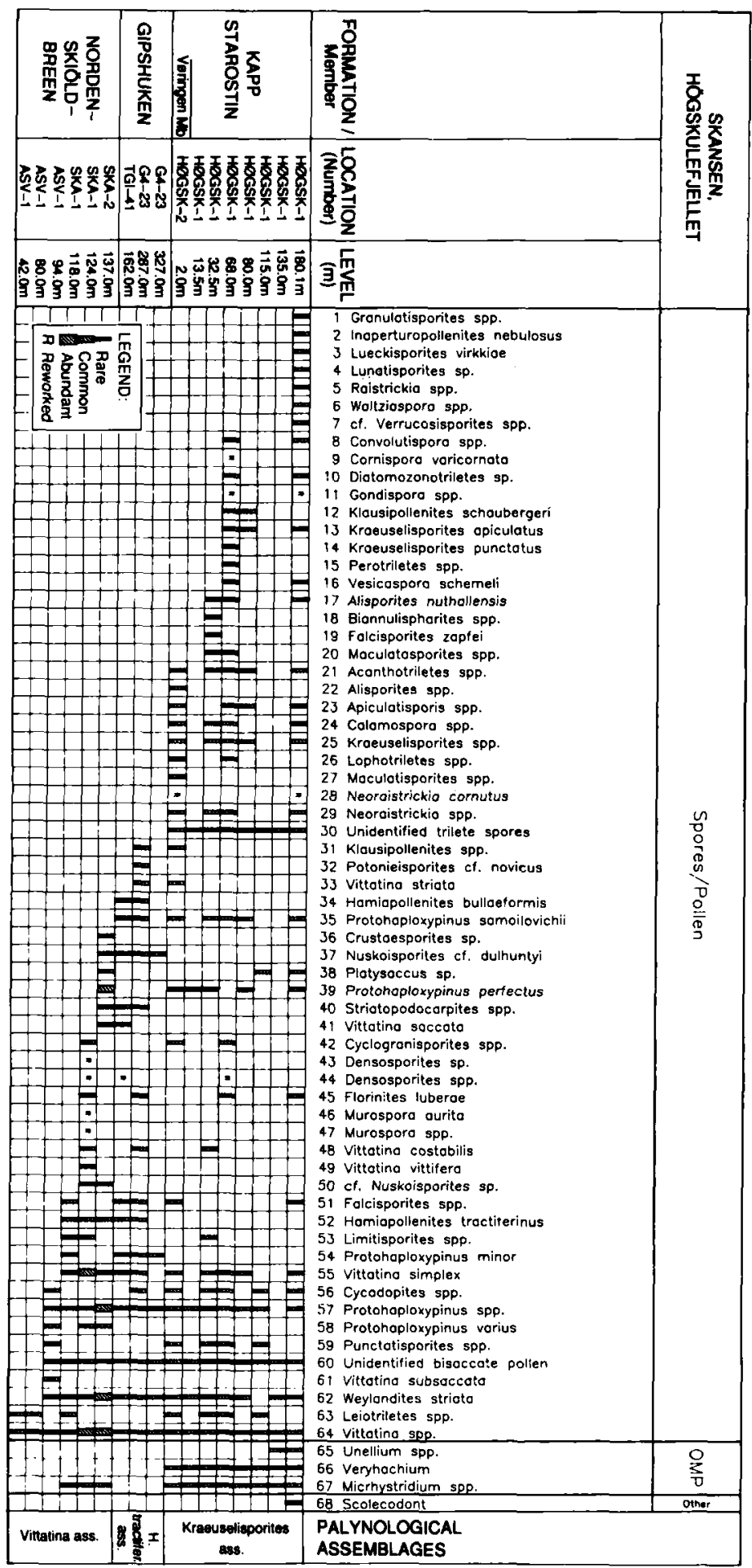

Fig. 7. Distribution chart for the Skansen and Høgskulefjellet localities, representing the Permian succession of East-Mid Central Spitsbergen. 


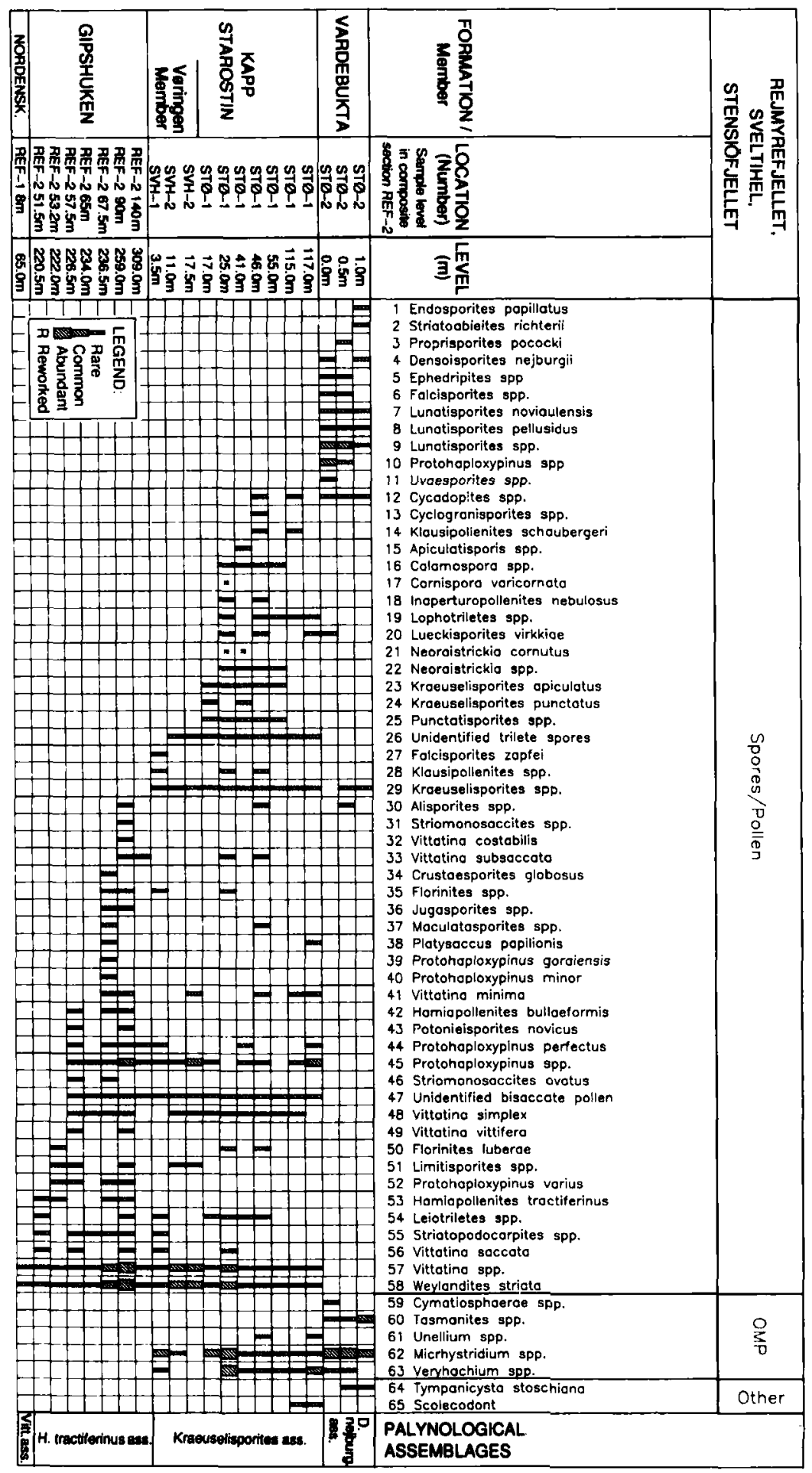

Fig. 8. Distribution chart for the Rejmyrefjellet, Sveltihel and Stensiöfjellet sections, representing the Permian succession of Eastern Central Spitsbergen. 


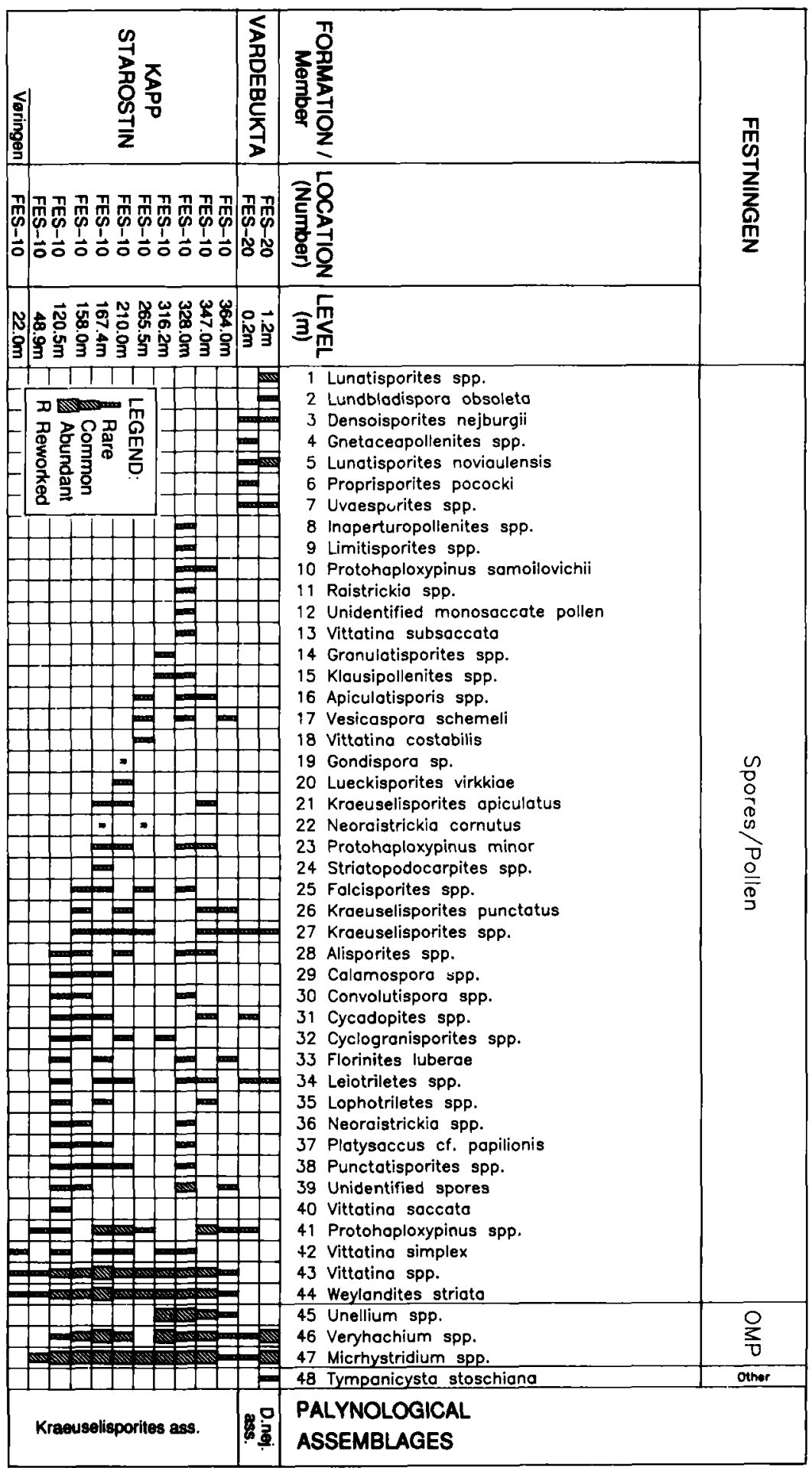

Fig. 9. Distribution chart for the Festningen locality, Western Spitsbergen. 


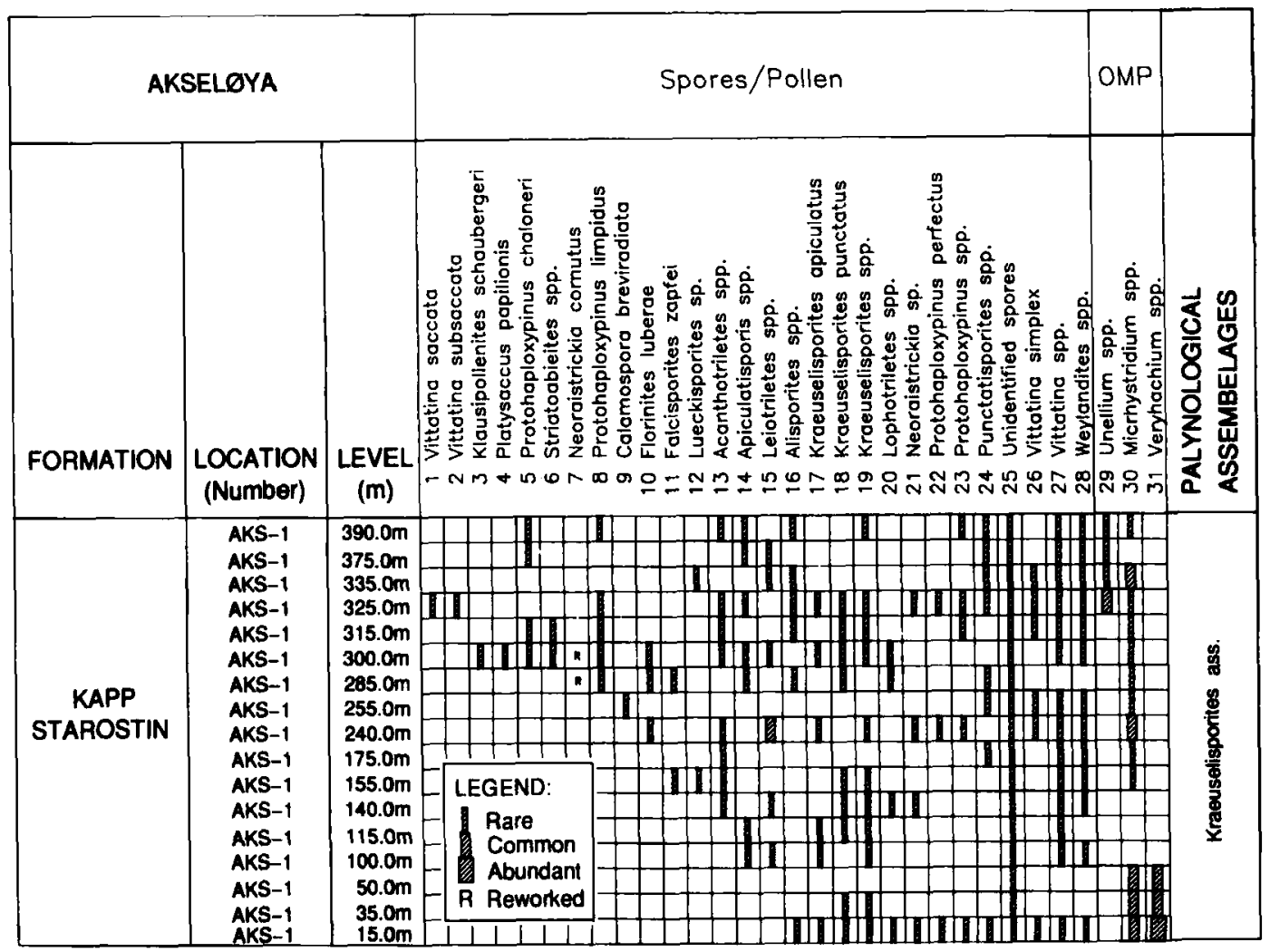

Fig. 10. Distribution chart for the Akseløya locality in Bellsund, Western Spitsbergen.

\section{Palynological assemblages and age}

In order to restrict the assemblages of the Permian succession downwards and upwards, a few samples were analysed from the Carboniferous Kapitol and Cadellfjellet Members as well as from the lowermost Triassic Vardebukta Formation.

The Densosporites assemblage

Palynological description. - This very low diversity assemblage is characterised by various spore genera Densosporites, Reticulatisporites and Murospora. Whether this assemblage is reworked or in situ is not certain due to the low diversity of palynomorphs.

Occurrence. - The assemblage is recorded in the Kapitol Member of the lowermost Nordenskiöldbreen Formation (Fig. 2) at localities Trollfuglfjella and Kolosseum (Figs. 5 and 6).
Palynological correlation and age. - This assemblage does not seem to correlate with other Late Carboniferous assemblages, although Clayton et al. (1977) reported various Densosporites from their Stephanian ST-Zone. This could indicate that the assemblage is reworked, and it appears similar to Playford's (1962a, b) assemblages from the Lower Carboniferous succession in Svalbard. However, this may not exclude that some of these species are in situ. The samples are recorded in beds dated as Moscovian to early Gzhelian based on fusulinids (Nilsson 1988). Brachiopods and conodonts give a general middle to latest Carboniferous (Gzhelian) age, while bryozoans suggest a Kasimovian to Gzhelian age based on correlation with the Urals (Nakrem et al. 1992), although some bryozoan species are also typical of the Asselian to Artinskian succession in the Timan-Pechora Basin, Russia (Nakrem et al. 1992). 
Mid-Central Spitsbergen

(Trolltuglfjella, Kapp Wijk)

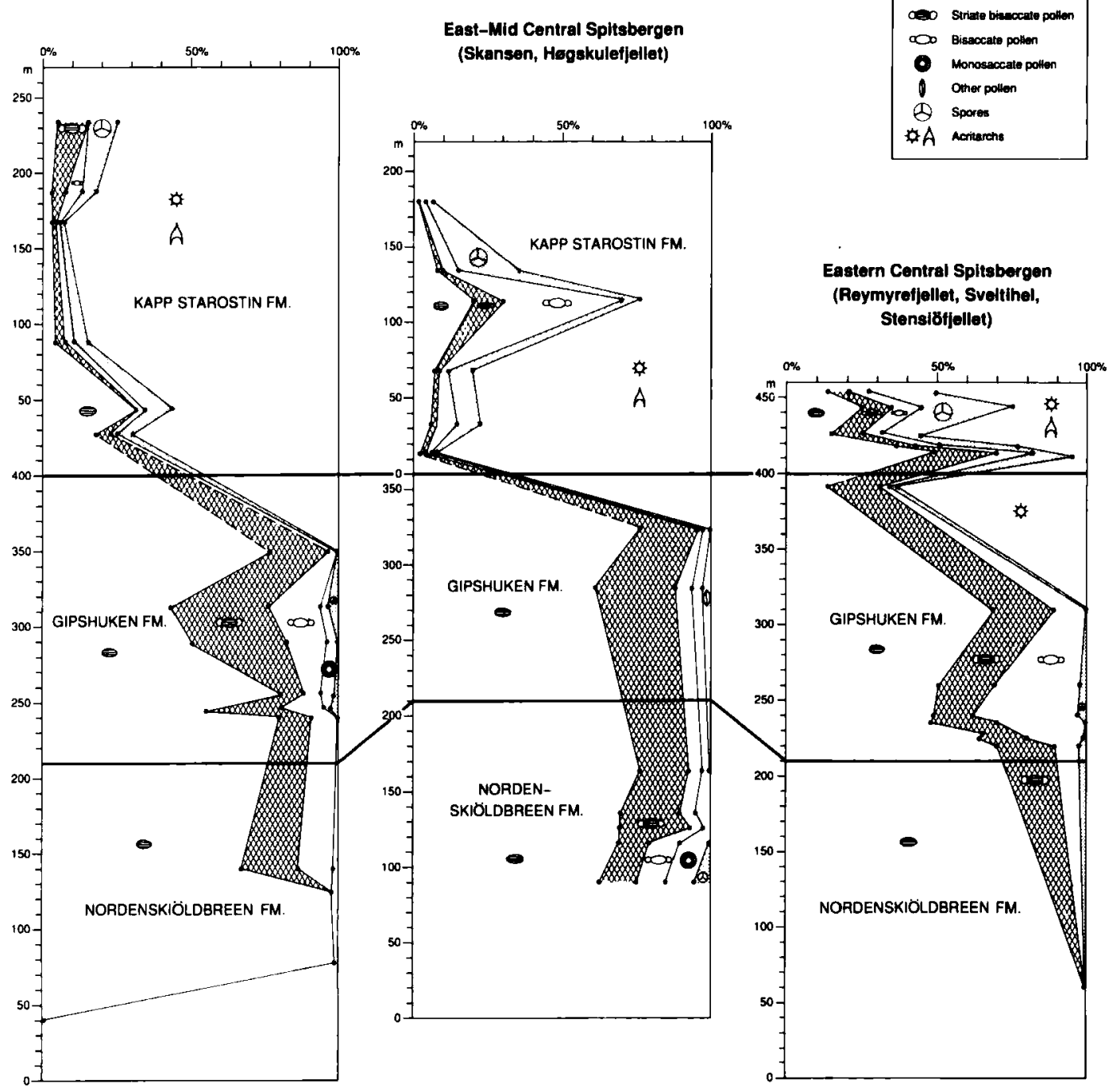

Fig. 11. Semiquantitative variations between some main palynomorph groups through the Permian succession in three areas on Spitsbergen, Svalbard.

\section{The Vittatina assemblage}

Palynological description. - The assemblage is characterised by having low diversity, and very few palynomorphs are recorded. In general, only poorly preserved Vittatina spp. and Leiotriletes spp. are present. However, specimens of the genera Protohaploxypinus, Cycadopites and Cyclogranisporites are recorded at two localities.

Occurrence. - This assemblage is recorded within the lower part of the Tyrrellfjellet Member of the Nordenskiöldbreen Formation (Fig. 2) at all studied localities, including Kolosseum, Trollfuglfjella, Skansen and Rejmyrefjellet (Figs. 5-8).

Palynological correlation and age. - Comparison with other assemblages is difficult due to the very poor recovery and low diversity. The assemblage mainly contains Vittatina, and based on fusulinids from the lower Tyrrellfjellet Member is given a 
Table 1. Recorded palynomorphs from the Permian succession of Spitsbergen, Svalbard listed alphabetically

Acanthotriletes spp.

Alisporites nuthallensis Clarke 1965

Alisporites spp.

Apiculatisporis spp.

Biannulispharites spp.

Calamospora spp.

Calamospora breviradiata Kosanke 1950

Convolutispora spp.

Cornispora varicornata R! Staplin \& Jansonius 1961

Crustaesporites globosus Leschik 1956

Crustaesporites spp.

Cycadopites spp.

Cyclogranisporites spp.

Cymatiosphaerae spp.

Densoisporites nejburgii (Schulz) Balme 1970

Densoisporites spp.

Densosporites anulatus R! (Loose) Smith \& Butterworth 1967

Densosporites rarispinosus R! Playford 1962

Densosporites spitsbergensis R! Playford 1962

Densosporites spp.

Densosporites varimarginatus R! Playford 1962

Endosporites spp.

Ephedripites spp.

Falcisporites spp.

Falcisporites zapfei Potonié \& Klaus 1954

Florinites luberae Samoilovich 1953

Florinites spp.

Gondispora sp.

Gondispora spp.

Granulatisporites spp.

Hamiapollenites bullaeformis (Samoilovich) Jansonius 1962

Hamiapollenites tractiferinus (Samoilovich) Jansonius 1962

Inaperturopollenites nebulosus Balme 1970

Jugasporites spp.

Klausipollenites schaubergeri (Potonié \& Klaus) Jansonius 1962

Klausipollenites spp.

Kraeuselisporites apiculatus Jansonius 1962

Kraeuselisporites punctatus Jansonius 1962

Kraeuselisporites spp.

Laevigatosporites spp.

Leiotriletes spp.

Limitisporites spp.

Lophotriletes spp.

Lueckisporites sp.

Lueckisporites virkkiae (Potonié \& Klaus) Clarke 1965

Lunatisporites noviaulensis Leschik 1956

Lunatisporites pellusidus (Goubin) Balme 1970

Lunatisporites spp.

Maculatasporites spp.

Micrhystridium spp.

Murospora aurita R! (Waltz) Playford 1962

Murospora spp. R!

Neoraistrickia cornatus R! (Andreyeva) Hart 1965

Neoraistrickia sp.

Neoraistrickia spp.

Nuskoisporites dulhuntyi Potonié \& Klaus 1954

Nuskoisporites sp.

Perotriletes spp.

Platysaccus papilionis Potonié \& Klaus 1954

Plarysaccus sp.

Potoniesporites novicus Bharadwaj 1954
Proprisporites pococki Jansonius 1962

Protohaploxypinus amplus (Balme \& Hennelly) Hart 1964

Protohaploxypinus chaloneri Clarke 1965

Protohaploxypinus goraiensis (Potonié \& Lele) Hart 1964

Protohaploxypinus limpidus (Balme \& Hennelly) Balme \&

Playford 1968

Protohaploxypinus minor (Klaus) Clarke 1965

Protohaploxypinus perfectus (Naumova) Samoilovich 1953

Protohaploxypinus samoilovichii (Jansonius) Hart 1964

Protohaploxypinus spp.

Protohaploxypinus varius (Bharadwaj) Balme 1970

Punctatisporites spp.

Raistrickia spp.

Reticulatisporites sp.

Scolecodont

Striatoabieites spp.

Striatopodocarpites cancellatus (Balme \& Hennelly) Hart 1965

Striatopodocarpites spp.

Striatopodocarpites varius (Bharadwaj) Balme 1970

Striomonosaccites ovatus Bharadwaj 1962

Striomonosaccites rotatus (Bharadwaj) Hart 1965

Striomonosaccites spp.

Tasmanites spp.

Unellium spp.

Veryhachium spp.

Vesicaspora schemeli Klaus 1963

Vittatina costabilis Wilson 1962

Vittatina minima Jansonius 1962

Vittatina saccata (Hart) Jansonius 1962

Vittatina simplex Jansonius 1962

Vittatina spp.

Vittatina subsaccata Samoilovich 1953

Vittatina vittifera (Luber \& Waltz) Samoilovich 1953

Waltziaspora spp.

Weylandites striata (Luber) Samoilovich 1953

Fig. 12. Selected spores and polyplicate pollen from the Nordenskiöldbreen and Gipshuken Formations. Each figured palynomorph is located by abbreviated section name, sample level, PMO number and slide coordinates to an England Finder. Scale is added.

1. Leiotriletes sp. TRO-5, $43 \mathrm{~m}$, PMO 139.075, H47

2. Lophotriletes sp. TRO-5, 43 m, PMO 139.075, T55/4

3. Cf. Vittatina sp. TRO-3, $130 \mathrm{~m}$, PMO 139.076, R49

4. Vittatina vittifera TRO-5, $32 \mathrm{~m}$, PMO $139.077, \mathrm{U} 49 / 2$

5. Vittatina simplex TRO-3, $140 \mathrm{~m}$, PMO $139.078, \mathrm{~F} 52 / 4$

6. Weylandites striata, TRO-5, $32 \mathrm{~m}$, PMO 139.077, U47/3

7. Vittatina saccata TRO-5, $103 \mathrm{~m}$, PMO 139.079, R55

8. Vittatina sp. TRO-5, $43 \mathrm{~m}$, PMO 139.075, N55/1

9. Vittatina cf. vittifera TRO-5, $103 \mathrm{~m}$, PMO $139.079, \mathrm{C} 54 / 4$

10. Vittatina sp. TRO-3, $140 \mathrm{~m}$, PMO $139.078,060$

11. Vittatina vittifera TRO-5, $103 \mathrm{~m}$, PMO 139.079, C54

12. Vittatina sp. G4-16, $287 \mathrm{~m}$, PMO 139.080, S29/4 


\section{NORDENSKIÖLDBREEN \& GIPSHUKEN FORMATIONS}
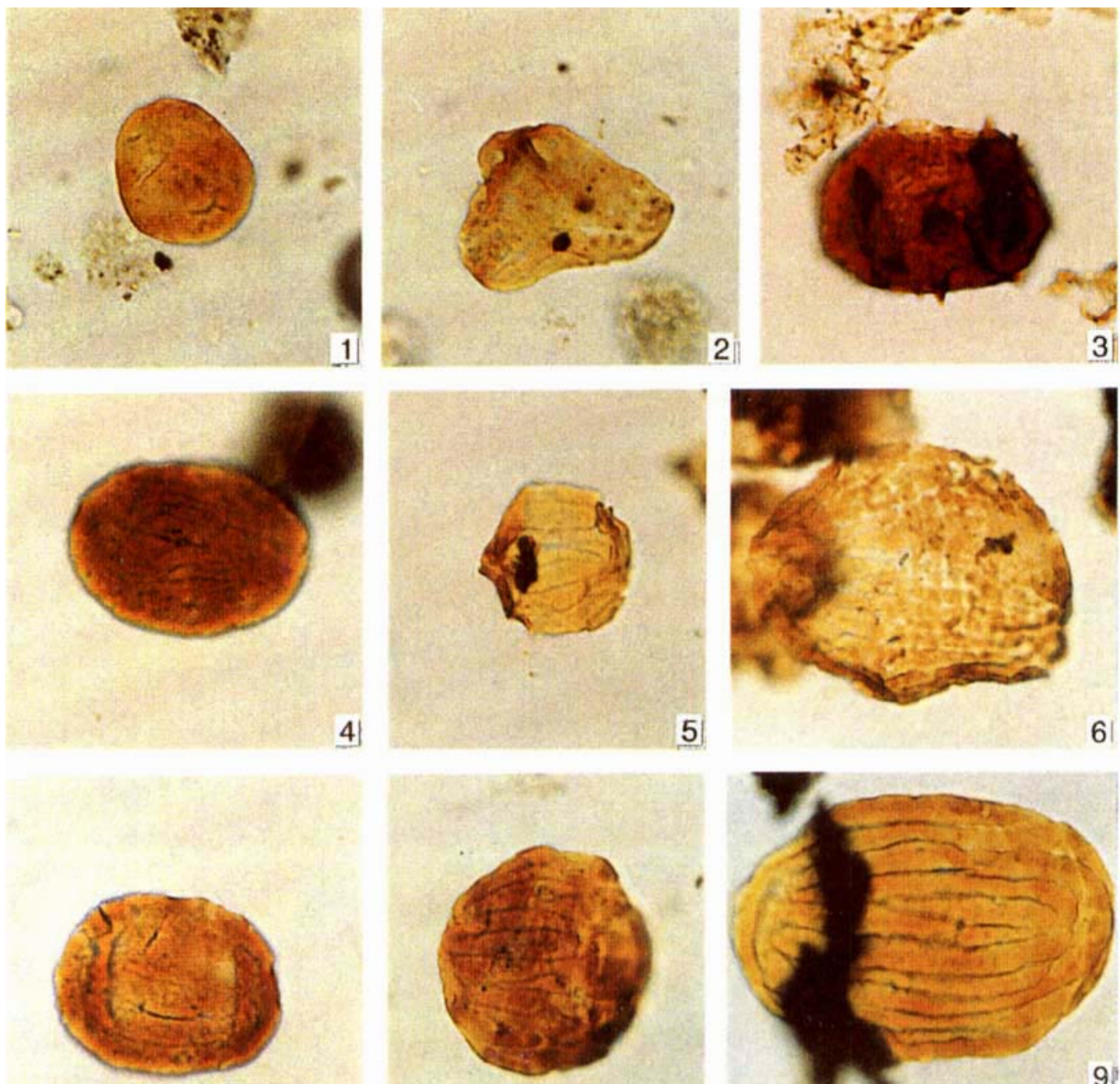
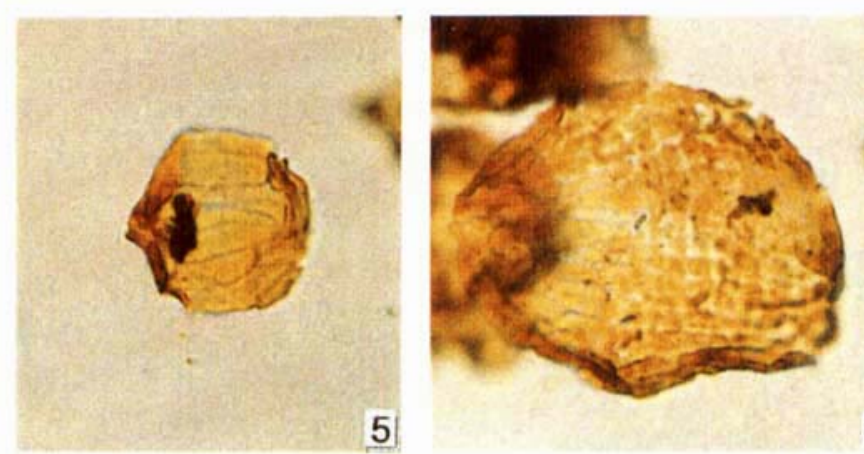

4

5
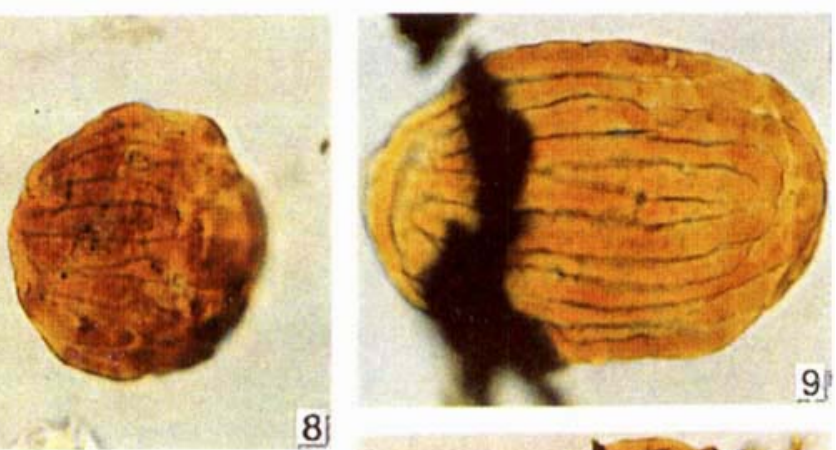

7

8)

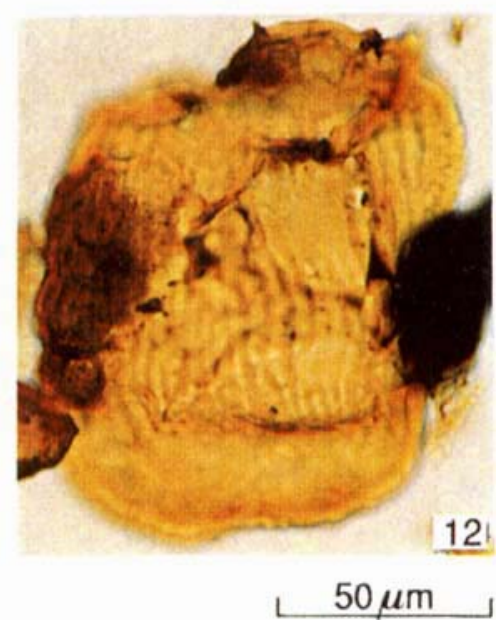

11
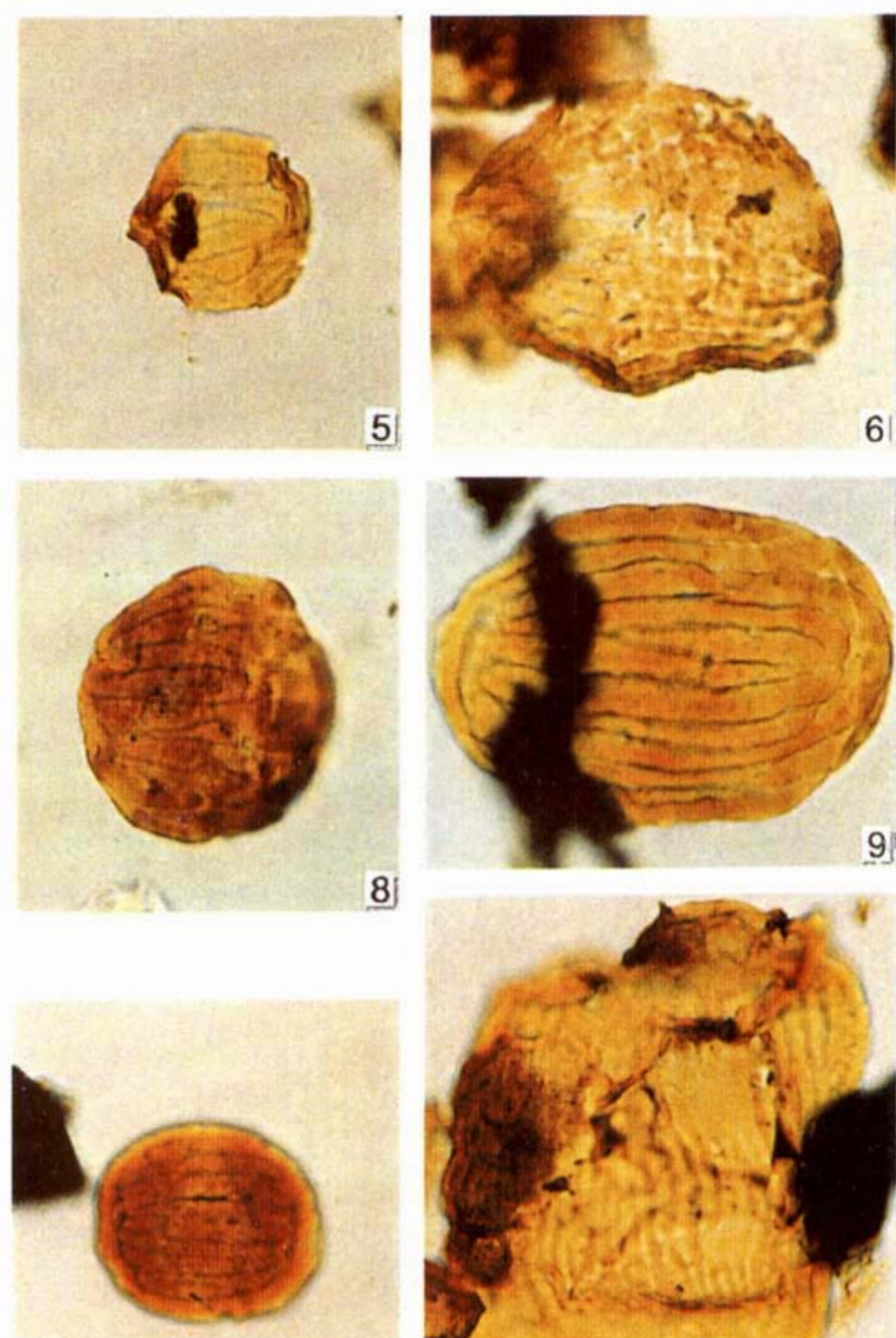

9]

10

12 
80 G. Mangerud and R. M. Konieczny

\section{NORDENSKIÖLDBREEN \& GIPSHUKEN FORMATIONS}
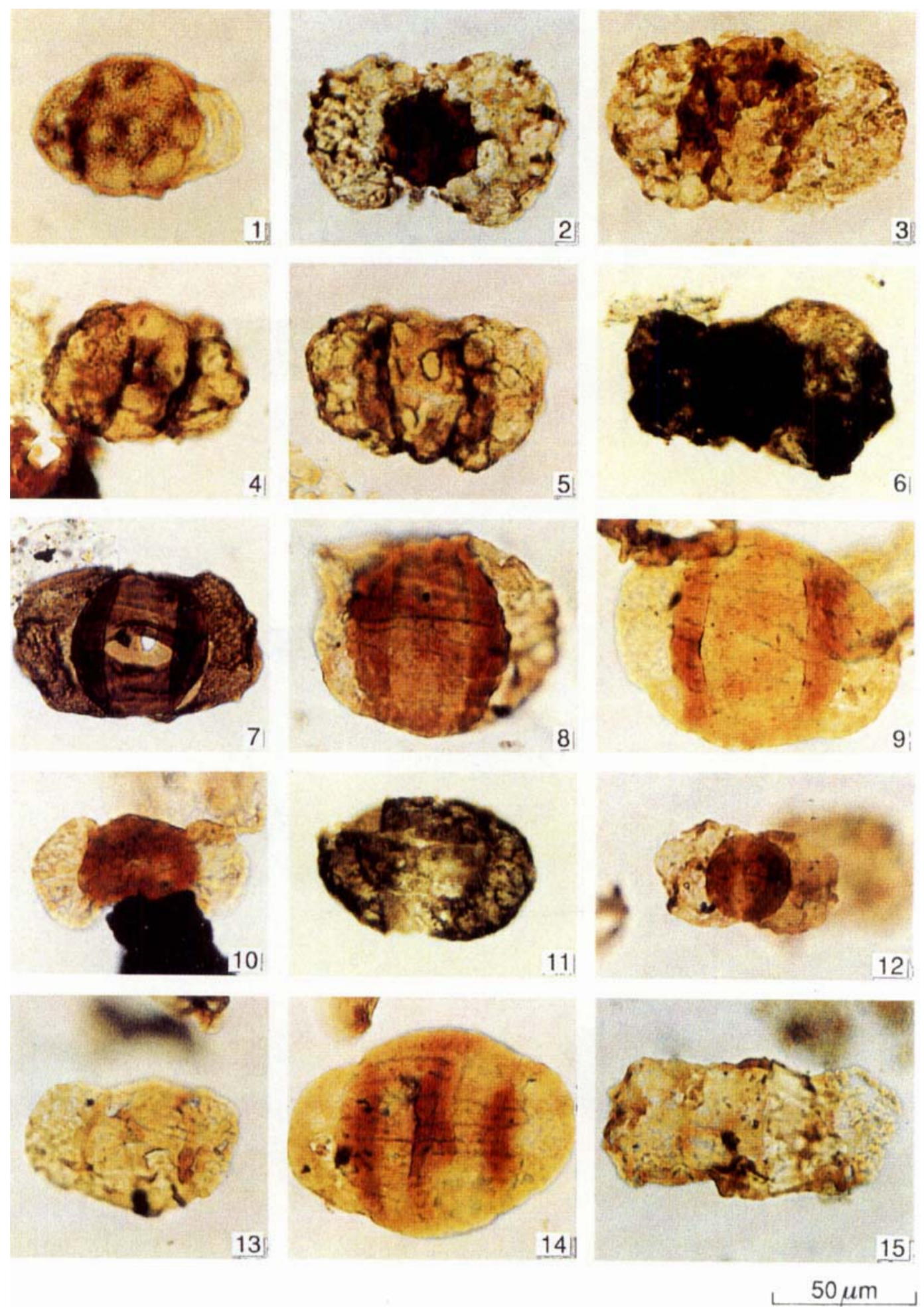
late Gzhelian to early Asselian age (Nilsson \& Davydov pers. comm. 1992). Few other age diagnostic fossil groups are recorded in this part of the succession. Palynomorphs as well as corals are inconclusive regarding the CarboniferousPermian boundary (Ezaki \& Kawamura 1992). The fusulinids have therefore been found to give the best dating to the present of these beds.

\section{The Hamiapollenites tractiferinus assemblage}

Palynological description. - This assemblage is dominated by different species of the polyplicate genus Vittatina (Fig. 11), including $V$. costabilis, $V$. saccata, $V$. saccifer, $V$. subsaccata, $V$. simplex and $V$. vittifera. Striate bisaccate pollen include various Protohaploxypinus and Striatopodocarpites species, and Hamiapollenites tractiferinus, as well as $H$. bullaeformis. The latter appears somewhat higher in the succession compared with H. tractiferinus. Other bisaccate pollen include Klausipollenites, Alisporites nuthallensis, A. spp., Jugasporites, Platysaccus papilionis and Limitisporites. Monosaccate pollen include Nuskoisporites dulhuntyi, Cordaitina, Florinites luberae, Striomonosaccites and Potoniesporites

Fig. 13. Selected bisaccate pollen from the Nordenskiöldbreen and Gipshuken Formations. Each figured palynomorph is located by abbreviated section name, sample level in composite section, PMO number and slide coordinates to an England Finder. Scale is added.

1. Unidentified bisaccate pollen TRO-3, $140 \mathrm{~m}$, PMO 139.078, $\mathrm{V} 42 / 2-4$

2. Platysaccus sp. TRO-5, $32 \mathrm{~m}$, PMO $139.077, \mathrm{C} 53 / 2$

3. Unidentified bisaccate pollen, TRO-3, $140 \mathrm{~m}$, PMO $139.078, \mathrm{~V} 41 / 2-4$

4. Limitisporites sp. TRO-3, $140 \mathrm{~m}$, PMO 139.078, M62

5. Limitisporites sp. TRO-3, $140 \mathrm{~m}$, PMO $139.078, \mathrm{R} 61 / 2$

6. Platysaccus sp. SKA-2, 137 m, PMO 139.081, T43/2

7. Protohaploxypinus samoilovichii KOL-4, $2.0 \mathrm{~m}$, PMO 139.082, D64

8. Protohaploxypinus sp. TRO-5, 103 m, PMO 139.079, K51/2

9. Protohaploxypinus sp. TRO-5, $103 \mathrm{~m}$, PMO 139.079, A51/ 3-4

10. Striatopodocarpites sp. TRO-5, $103 \mathrm{~m}$, PMO 139.079, 147/4

11. Protohaploxypinus sp. SKA-2, $137 \mathrm{~m}$, PMO 139.081, C59/2

12. Striatopodocarpites sp. TRO-5, $103 \mathrm{~m}, \mathrm{PMO} 139.079, \mathrm{~T} 63 / 1$

13. Hamiapollenites bullaeformis TRO-5, $32 \mathrm{~m}$, PMO 139.077, $\mathrm{N} 41 / 2$

14. Hamiapollenites bullaeformis TRO-5, 103 m, PMO 139.079, D58/1

15. Hamiapollenites tractiferinus TRO-5, $32 \mathrm{~m}$, PMO 139.077, F41/4 novicus. Monosaccate pollen appear regularly in this assemblage, but never comprise more than about $5 \%$ of the total assemblage (Fig. 11). Spores occur also in low numbers, and include several genera such as Cyclogranisporites, Leiotriletes, Maculatasporites and Punctatisporites.

Occurrence. - The assemblage occurs in the upper parts of the Tyrrellfjellet Member of the Nordenskiöldbreen Formation and throughout the Gipshuken Formation (Fig. 2) at the localities Kolosseum, Trollfuglfjella and Skansen (Fig. 3). At Rejmyrefjellet the assemblage is only recorded in the Gipshuken Formation (Fig. 8). A similar assemblage was reported from Nordaustlandet, Svalbard (Mangerud \& Konieczny 1991) in the upper part of the Nordenskiöldbreen Formation and the lower part of the Gipshuken Formation.

Palynological correlation and age. - The assemblage resembles the Weylandites striatus (syn. Vittatina striata) - Protohaploxypinus perfectus and the Limitisporites monstruosus - Vittatina costabilis Assemblage Zones in the Sverdrup Basin (Utting 1989). The first assemblage zone is of late Asselian to Sakmarian age based on fusulinids (Nassichuk \& Wilde 1977), foraminifera (B. L. Mamet, in Utting 1989) and conodonts (A. C. Higgins, in Utting 1989), while the latter is of late Artinskian age based on conodonts (C. M. Henderson, in Utting 1989). Our assemblages differ in $H$. tractiferinus, being less common and $L$. monstruosus seeming to be absent. The latter feature could indicate a closer resemblance with the Weylandites striatus - Protohaploxypinus perfectus Assemblage Zone although our assemblages are more diverse.

In Svalbard the upper part of the Tyrrellfjellet Member is dated as middle Asselian to Sakmarian based on fusulinids (Nilsson pers. comm. 1993), while conodonts in the uppermost fusulinid zone indicate a late Sakmarian-Artinskian age (Nakrem et al. 1992). The Gipshuken Formation is in general poorly dated, and long-ranging forms have primarily been reported. Brachiopods have an Asselian-Artinskian affinity (Gobbett 1963) while a conodont recorded indicates an Artinskian-Kungurian age (Nakrem et al. 1992). In the upper part of the Gipshuken Formation, foraminifera indicate an Artinskian age (Sosipatrova 1967). 
The Kraeuselisporites spp. assemblage

Palynological description. - The assemblage is totally dominated by acritarchs which at some levels account for up to $90 \%$ of the total palynomorph content (Fig. 11). The acritarchs mainly belong to the genera Micrhystridium, Unellium and Veryhachium. Polyplicate pollen are still common, but are less diverse compared to the underlying assemblages, mainly represented by Weylandites striata and Vittatina simplex. Striate bisaccate pollen are consistently present, but occur in low numbers, with the most common genus being Protohaploxypinus. Lueckisporites virkkiae is present but rare, and only a few Lunatisporites sp. (syn. Taeniasporites sp.) are recorded in the upper part. Other bisaccate pollen genera include Klausipollenites, Falcisporites, Alisporites, Platysaccus and Vesicaspora. Florinites occurs rarely. A characteristic feature is the income of several new spore genera including Neoraistrickia, Leiotriletes, Maculatasporites, Waltziaspora, Calamospora, Convolutispora, Diatomozonotriletes, Apiculatisporites, Lophotriletes, Cyclogranisporites, Kraeuselisporites, Granulatisporites and Acanthotriletes, as well as the pollen grain Inaperturopollenites nebulosus.

Occurrence. - This assemblage occurs in the Kapp Starostin Formation (Fig. 2), but palynomorphs from the uppermost part of the formation have not been recorded anywhere on Spitsbergen. The assemblage is recorded at localities Akseløya, Festningen, Høgskulefjellet, Kapp Wijk, Kapp Wærn, Stensiöfjellet and Sveltihel (Figs. 5-8, 10).

Palynological correlation and age. - The assemblage resembles that from the lower part of the Kapp Starostin Formation on Nordaustlandet (Mangerud \& Konieczny 1991) and from the Miseryfjellet Formation on Bjørnøya (Vigran \& Mørk unpubl.). It is also similar to the Dyupetalum sp. - Neoraistrickia and Scutasporites Lunatisporites zones from the Barents Shelf (Mangerud, unpubl. data). The latter zones have basically been dated by correlation with the Roadian and Wordian assemblages of the Sverdrup Basin (Utting 1985, 1989) where marine fauna control is well established. Utting (1989) defined an Alisporites insignis-Triadispora sp. Assemblage Zone of late Artinskian to Roadian age and a Taeniaesporites sp. Assemblage Zone of Wordian age. Both these assemblages are similar to the palynofloras from the Kapp Starostin Formation. The Late Permian Vittatina assemblages described from East Greenland (Balme 1980; Piasecki 1984) are similar in the presence of Lueckisporites virkkiae, Florinites luberae and of spinose acritarchs in all samples (Balme 1980). They seem, however, to differ in quantitative composition and in very rare occurrence of spores. In the Timan-Pechora Basin, Lueckisporites virkkiae and Taeniaesporites noviaulensis occur only in the Tatarian (Varyukhina 1971; Molin \& Koloda 1972). However, both these species occur in beds dated to Wordian (= Kazanian) age in the Sverdrup Basin (Utting pers. comm. 1992). The Late Permian assemblages from Russia are in general similar to the assemblages from the Kapp Starostin Formation.

Due to the poor preservation and many barren samples, the Late Permian Svalbard assemblages cannot be dated precisely in terms of stages. In the Sverdrup Basin and in the Barents Sea area it is possible to distinguish the Ufimian and Kazanian on the presence of Scutasporites cf. unicus, Ahrensisporites and Lunatisporites sp. (syn. Taeniaesporites sp.) which appear in the Kazanian (Utting pers. comm. 1992, IKU in-house data). Only a few poorly preserved Lunatisporites are recorded from the upper part of the Kapp Starostin Formation on Svalbard, but it is only possible on present data to indicate a general Ufimian

Fig. 14. Selected pollen from the Tyrrellfjellet Member of the Nordenskiöldbreen and Gipshuken Formations and spores from the Kapitol and Cadellfjellet Members of the Nordenskiöldbreen Formation. Each figured palynomorph is located by abbreviated section name, sample level, PMO number and slide coordinates to an England Finder. Scale is added.

1. Nuskoisporites cf. dulhuntyi TRO-5, $43 \mathrm{~m}$, PMO 139.075, S50

2. Nuskoisporites sp. SKA-2, $137 \mathrm{~m}$, PMO 139.081, S29/4

3. Cf. Florinites sp. ST Ø-1, $25 \mathrm{~m}$, PMO 139.087, T53/3

4. Potoniesporites cf. novicus TRO-5, $103 \mathrm{~m}$, PMO 139.079, $\mathrm{X} 49 / 2$

5. Unidentified monosaccate pollen TRO-3, $140 \mathrm{~m}$, PMO 139.078, L44/3

6. Cordaitina sp. TRO-5, $43 \mathrm{~m}$, PMO 139.075 , H46/1

7. Crustaesporites sp. SKA-2, 137 m, PMO 139.081, M64/1

8. Potoniesporites novicus KOL-4, 2.0 m, PMO 139.082, W55 $/ 2$

9. Murospora aurita SKA-1, $124.5 \mathrm{~m}$, PMO 139.084, 332

10. Densosporites spp. SKA-1, 124.5 m, PMO 139.084, V32

11. Densosporites sp. SKA-1, $124.5 \mathrm{~m}$, PMO 139.084, G52

12. Densosporites spitsbergensis TRO-1, 7.0 m, PMO 139.085, S17 


\section{NORDENSKIÖLDBREEN \& GIPSHUKEN FORMATIONS}
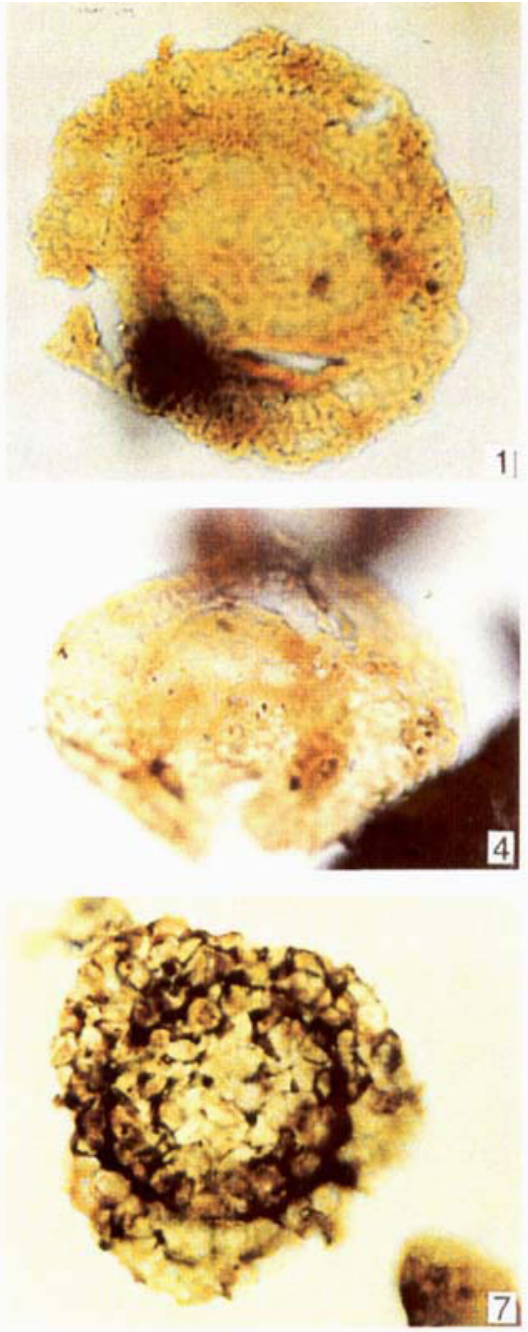

1
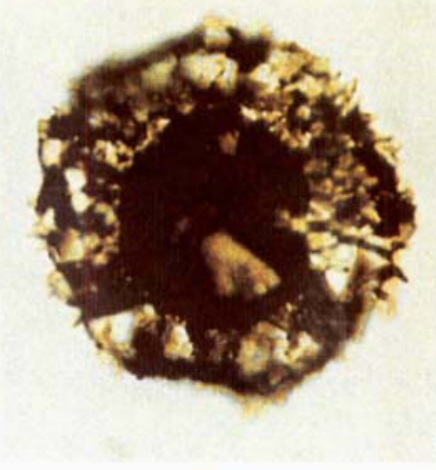

2

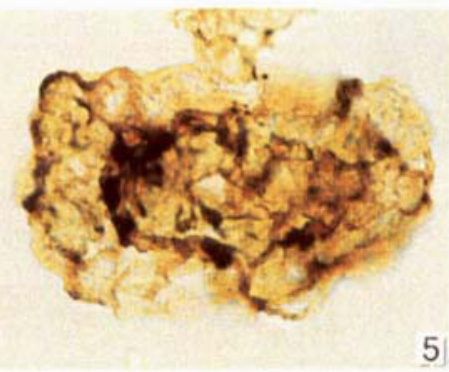

5

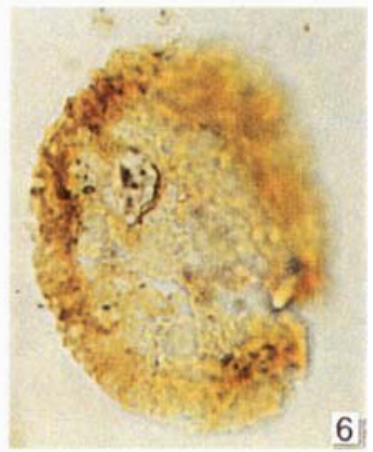

Reworked:

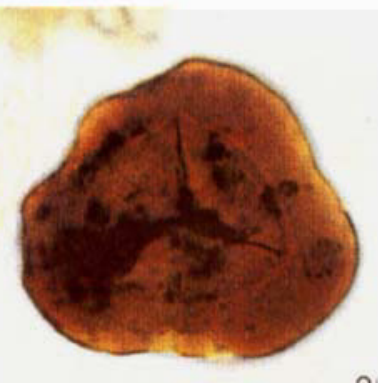

9

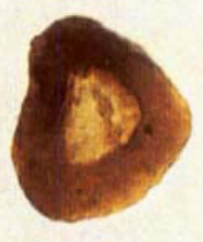

10

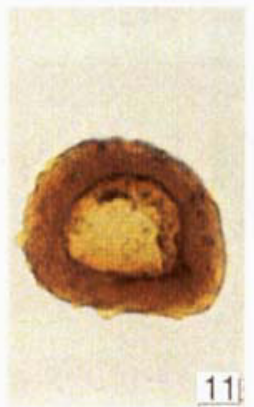

11

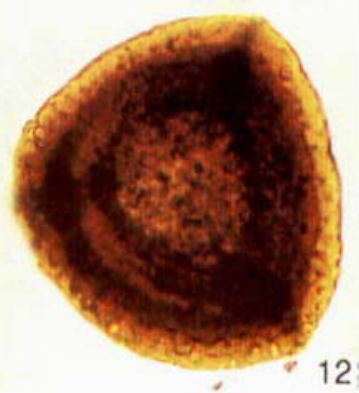

$50 \mu \mathrm{m}$ 


\section{KAPP STAROSTIN FORMATION}
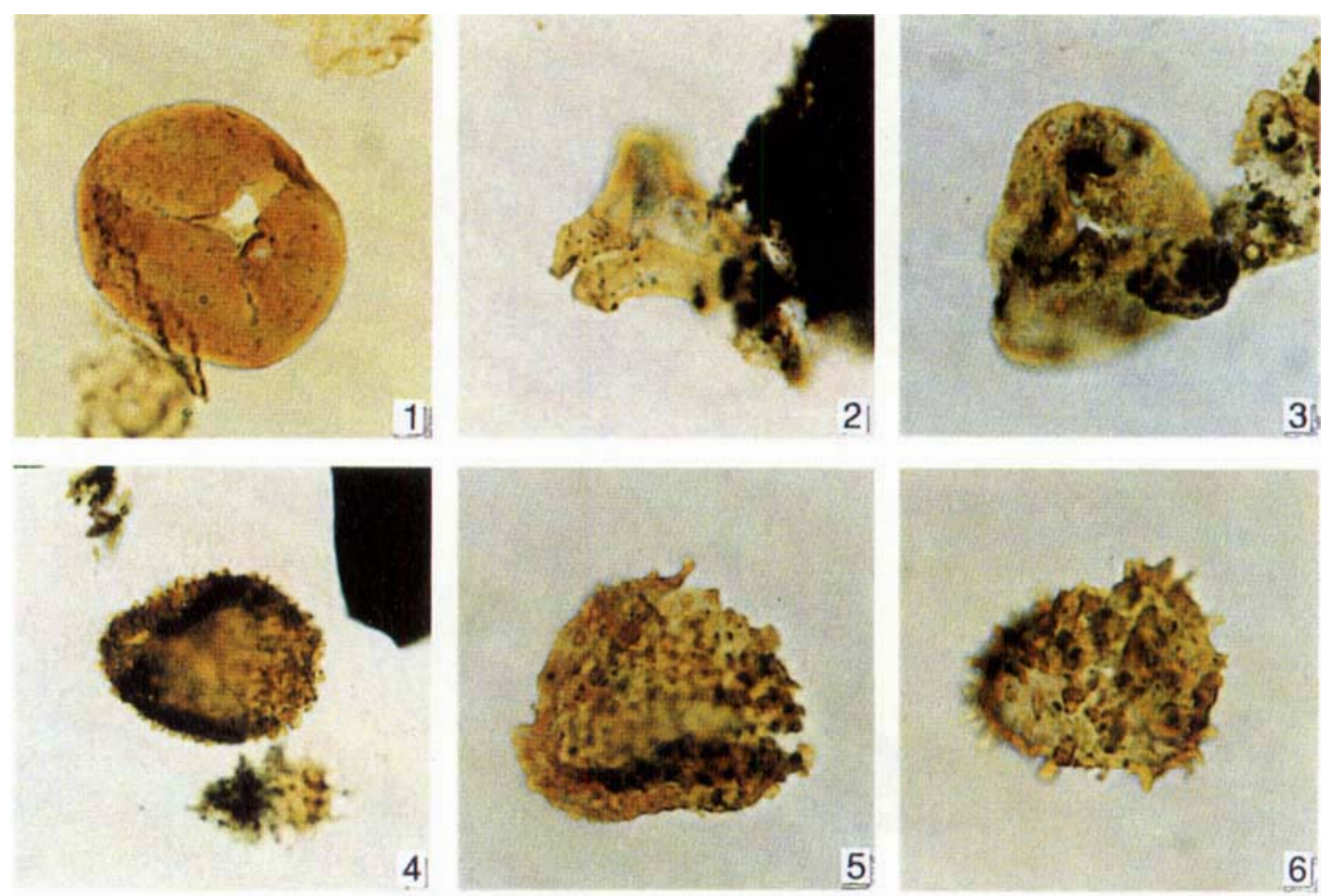

4

5 6
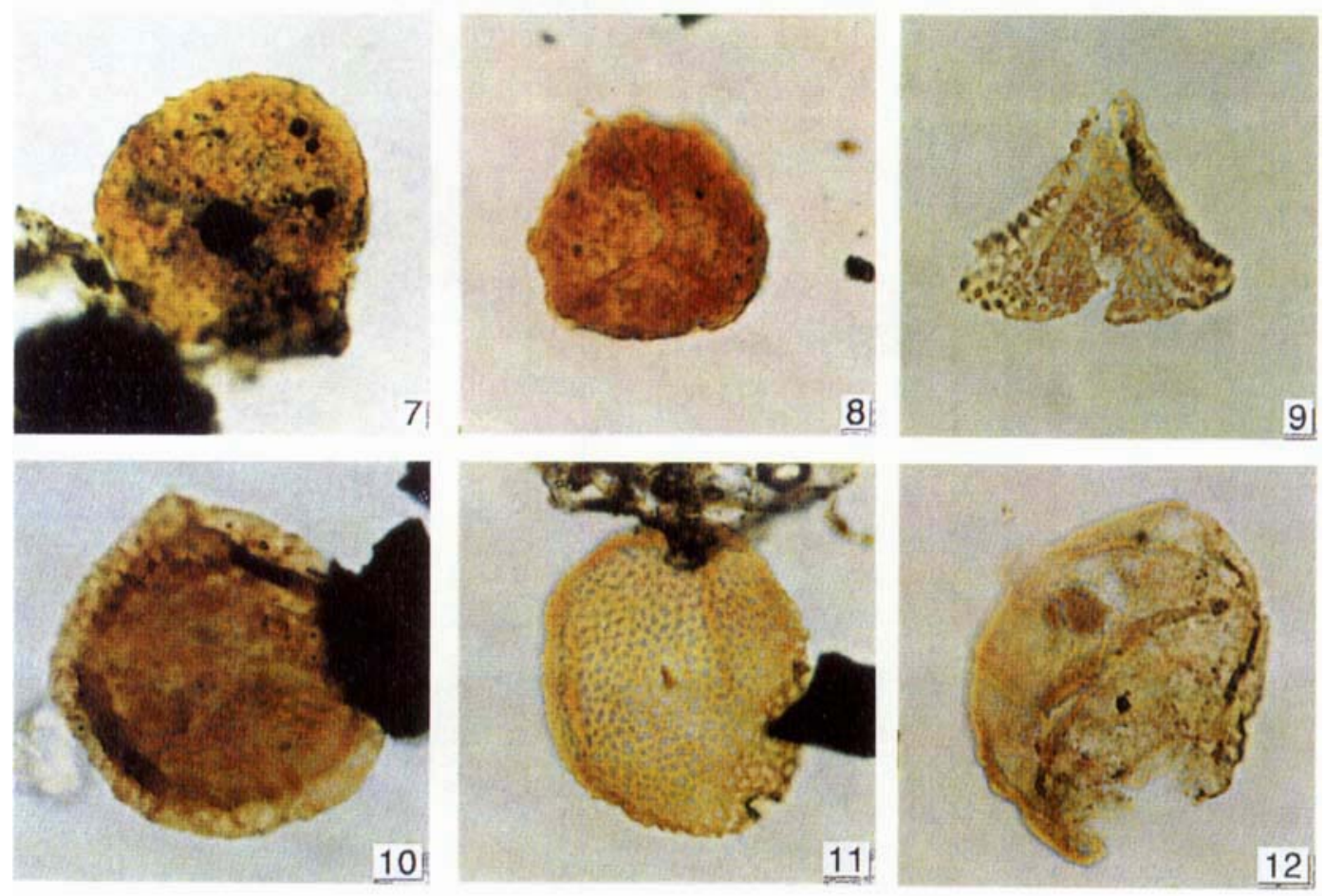

$50 \mu \mathrm{m}$ 
to Kazanian age. Probably due to low diversity and poor preservation, the palynoflora does not seem to differ significantly between the lower Vøringen Member and the overlying part of the formation.

Dating of the Kapp Starostin Formation based on brachiopods suggests a Kungurian to Midian (late Kazanian to early Tatarian) age (Nakamura et al. 1987, 1992). The Nakamura et al. zonation from 1987 was disputed as being controlled by environment rather than evolution (Stemmerik 1988), but the general age assignment of a latest Early Permian or earliest Late Permian to early Tatarian was also supported by Stemmerik. Conodonts from the lower Vøringen Member suggest a late Artinskian to early Kungurian age (Nakrem et al. 1992), while brachiopods suggest a Kungurian age for the Vøringen Member (Nakamura et al. 1992). Bryozoans suggest a Ufimian to Kazanian age for the overlying part of the formation (Nakrem 1991b).

The time-span of the proposed hiatus between youngest Permian and the ammonoid-dated Early Griesbachian succession on Spitsbergen has been debated for some time. Most publications based on fossil records suggest a hiatus spanning the uppermost Permian (Nakrem et al. 1992; Nakamura et al. 1987, 1992), but how much is missing is still a matter of discussion. The uppermost brachiopod faunas in Nakamura et al. (1992) suggest the lowermost part of the Tatarian to be present, implying that the Dzhulfian to Dor-

Fig. 15. Selected spores from the Kapp Starostin Formation. Each figured palynomorph is located by abbreviated section name, sample level, PMO number and slide coordinates to an England Finder. Scale is added.

1. Leiorriletes sp. KWI-5, $88 \mathrm{~m}$, PMO 139.088, B60

2. Waltziaspora sp. HØGSK-1, $180 \mathrm{~m}$ PMO 139.089, E46/3

3. Unidentified, trilete sporc ST $\emptyset-1,17 \mathrm{~m}$, PMO 139.090, D44/1

4. Apiculatisporis sp. HØGS-1, $180 \mathrm{~m}$, PMO 139.089, G54/2

5. Neoraistrickia sp. KWA-1, $3.6 \mathrm{~m}$, PMO 139.091, T61/3

6. Neoraistrickia sp. HØGS-1, $180 \mathrm{~m}$, PMO 139.089 , G54/2

7. Cf. Verrucosisporites sp. HØGS-1, $180 \mathrm{~m}$, PMO 139.089, $\mathrm{V} 54 / 3$

8. Kraeuselisporites sp. STØ-1, $115 \mathrm{~m}$, PMO 139.092, C48/3

9. Diatomozonotriletes sp. HØGS-1, $68 \mathrm{~m}$, PMO 139.093, L47

10. Kraeuselisporites apiculatus FES-10, $167.4 \mathrm{~m}$, PMO 139.094, F55/1

11. Maculatasporites sp. aff. Reticulatina HøGS-1, 22 m, PMO 139.095, P56

12. Inaperturopollenites nebulosus ST $-1,46 \mathrm{~m}$, PMO 139.096, D39/2 ashamian is missing. Dense sampling for palynology across the Permian-Triassic contact at Festningen and Stensiöfjellet (Fig. 3) does not give better resolution in the uppermost succession. Although fossil evidence is missing for the Tatarian, conformable lithological contacts between the Tempelfjorden and Sassendalen groups in some areas may indicate continuous, but very slow, sedimentation across the PermianTriassic boundary in western Spitsbergen (Mørk 1989).

The Densoisporites nejburgii assemblage

Palynological description. - The assemblage is characterized by various Lunatisporites species, Ephedripites, Densoisporites nejburgii, Uvaesporites spp., Proprisporites pococki and Tympanicysta stoschiana.

Occurrence. - The assemblage is recorded in the lowermost parts of the Vardebukta Formation (Fig. 2) at the Bertilryggen, Festningen and Stensiöfjellet localities.

Palynological correlation and age. - Proprisporites pococki and Densoisporites nejburgii are regarded as having their first occurrence from base Griesbachian, and are also reported from Griesbachian strata from the Barents Shelf (Hochuli et al. 1989) and East Greenland (Balme 1980). They occur in correlative beds where the Early Griesbachian ammonoid Otoceras boreale is reported (Tozer \& Parker 1968, Korchinskaya 1986). Tympanicysta stoschiana is restricted to the Griesbachian succession in the Arctic region (Balme 1980; Utting 1989; Mangerud; IKU inhouse data).

\section{Reworked material}

Reworked palynomorphs are identified at several levels in the Permian succession. Reworking of Carboniferous palynomorphs as various Densosporites spp. and Murospora spp. is recorded sporadically throughout. Reworking of Upper Devonian spores, including various genera of Ancyrospora spp., Grandispora spp., Samarisporites spp. and the species Cornispora varicornata seems to be restricted to the Upper Permian. In general, the reworked palynomorphs are better preserved than the in situ palynofloras. 


\section{Paleoenvironment}

The dominantly carbonate facies of the upper Nordenskiöld and the Gipshuken Formations are dominated by polyplicate pollen (Fig. 11), reflecting the arid climate that existed during the late Carboniferous and early Permian in the Svalbard area. The extremely low number of acritarchs also suggests a restricted marine environment.

The significant increase in acritarchs across the Gipshuken/Kapp Starostin contact reflects a dramatic shift in depositional environment, allowing marine microplankton to become abundant. The decrease in polyplicate pollen as well as the income of spores across the same formation contact (Fig. 11) reflect a change to more humid environmental conditions as suggested by Steel \& Worsley (1984).

\section{Conclusions}

The generally very poor preservation and the low number of productive samples of palynomorphs reduce the potential for refined zonation of the Permian succession of Spitsbergen, Svalbard.

Three palynological assemblages are, however, recognised in the uppermost Carboniferous-Permian succession. These include the Vittatina assemblage of late Gzhelian to early Asselian age, the Hamiapollenites tractiferinus assemblage of late Asselian to Sakmarian/?Artinskian age and the Kraeuselisporites assemblage of late Artinskian to early Tatarian (Midian) age.

A Late Carboniferous Densosporites assemblage restricts the oldest Permian assemblage downwards, while an Early Griesbachian Densoisporites nejburgii assemblage restricts the youngest Permian assemblage upwards.

The Permian palynofloras of Spitsbergen closely resemble Permian palynofloras recorded from the Barents Shelf (IKU in-house data), Bjørnøya (Vigran \& Mørk unpubl.), the Sverdrup Basin in Arctic Canada (Utting 1985, 1989) and from the Timan-Pechora Basin in Russia (for example Varyukhina 1971, 1980; Molin \& Koloda 1972; and Dyupina 1987). In addition, similarities are seen with those palynofloras described from East Greenland (Balme 1980; Piasecki 1984), although the general quantitative composition is different.
In general, the Early Permian is dominated by polyplicate pollen with abundant striate bisaccate pollen and regular appearance of monosaccate pollen, reflecting an arid climate. The Late Permian is dominated by acritarchs, while polyplicate and bisaccate pollen commonly appear to association with various trilete spores, reflecting a change to more humid environmental conditions.

Acknowledgements. - The authors thank the IKU staff for assistance, in particular A. Mørk for critical reading of the manuscript. We would also like to thank $C$. E. Dons, T. Hellem and $M$. Skaug for making unpublished field-logs available.

We thank J. Utting, ISPG, Geological Survey of Canada in Calgary for hospitality during visits to ISPG, for fruitful discussions on Permian palynology of the Arctic and for making available comparative material from the Sverdrup Basin. One of the authors (G. Mangerud) also thanks ISPG, in particular B. Beauchamp, for making it possible to join a field-party to collect comparative material from Ellesmere Island.

We thank S. Piasecki at the Geological Survey of Greenland (GGU) in Copenhagen for hospitality and for the opportunity to study material from Greenland.

We also gratefully acknowledge the companies who financially supported the Arctic Geoprogram and the Arctic Palcozoic project under the ongoing Arctic Correlation Program (A/S Norsk Shell, Amerada Hess Norge A/S, Amoco Norway Oil Company, BP Petroleum Development (Norway) Ltd., Elf Petroleum Norge A/S, Esso Norge a.s., Fina Exploration Norway, Mobil Exploration Norway, Norsk Agip A/S, Norsk Hydro a.s., Phillips Petroleum Company Norway, Saga Petroleum a.s. and Statoil).

Fig. 16. Selected bisaccate pollen from the Kapp Starostin Formation. Each figured palynomorph is located by abbreviated section name, sample level, PMO number and slide coordinates to an England Finder. Scale is added.

1. Lueckisporites virkkiae ST Ø-1, 25 m, PMO 139.083, Q46/1

2. Protohaploxypinus samoilovichii HØGS-1, $180 \mathrm{~m}$, PMO 139.089, H61/1

3. Protohaploxypinus perfectus KWA-1,3.6 m, PMO 139.091, T61

4. Protohaploxypinus sp. HØGS-1, $180 \mathrm{~m}$, PMO 139.089, E53/1

5. Klausipollenites sp. ST Ø-1, 46 m, PMO 139.096, B40/1

6. Cf. Limitisporites sp. KWE-1, 3.6 m, PMO 139.091, Q44/3

7. Falcisporites sp. HØGS-1, $180 \mathrm{~m}$, PMO 139.089, E51/2

8. Alisporites spp. KWÆ-1, 3.6 m, PMO 139.091, B40

9. Vesicaspora sp. KWÆ-1, 3.6 m, PMO 139.091, E53

10. Unidentified bisaccate pollen, KWE-1, $3.6 \mathrm{~m}$, PMO 139.091, T58/4

11. Vesicaspora schemeli KWA-1, 3.6 m, PMO 139.091, T52/2

12. Cf. Florinites sp. KWI-3, $187 \mathrm{~m}$, PMO 139.086 , R56/2 
Palynology of the Permian succession of Spitsbergen, Svalbard 87

\section{KAPP STAROSTIN FORMATION}
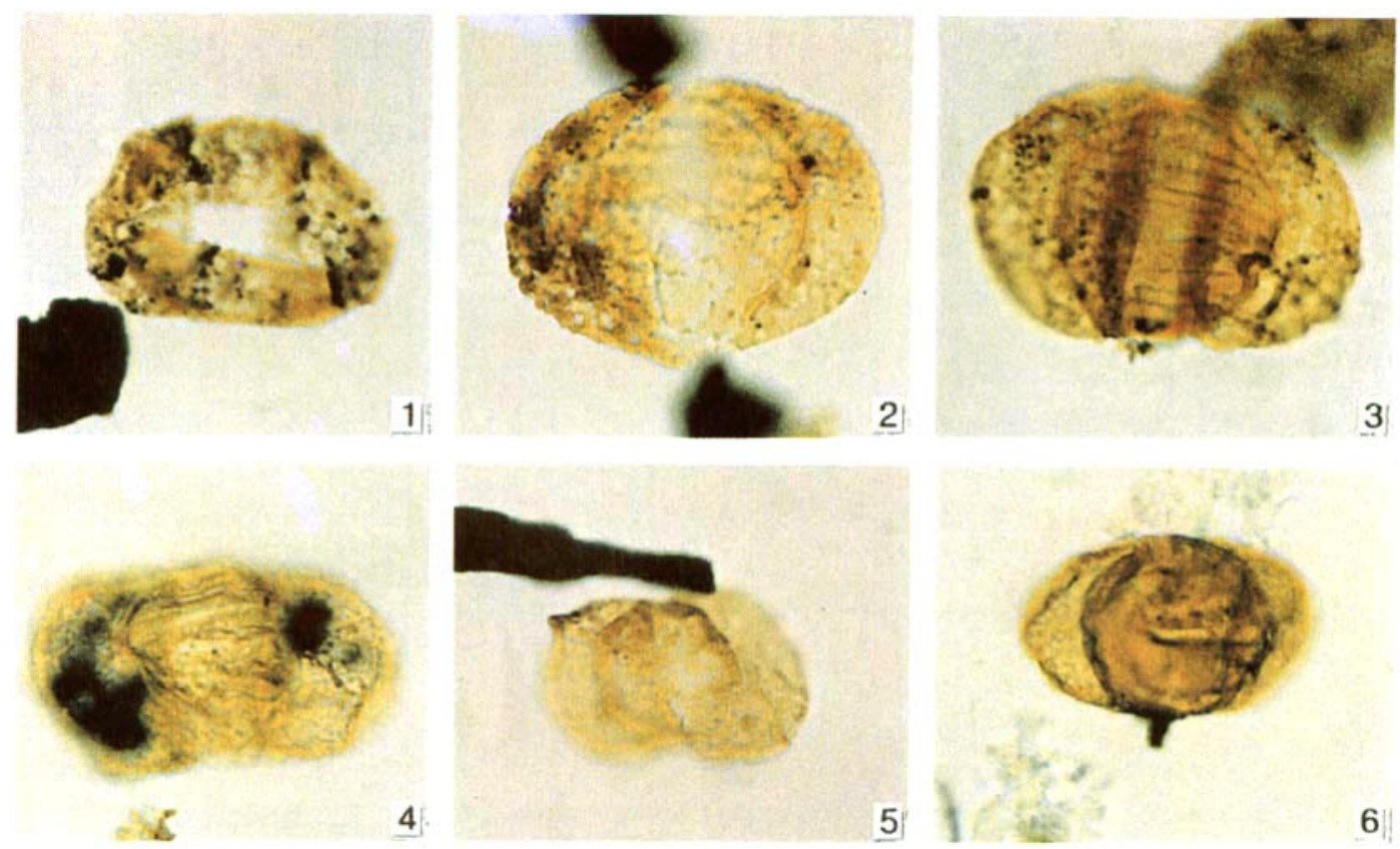

4
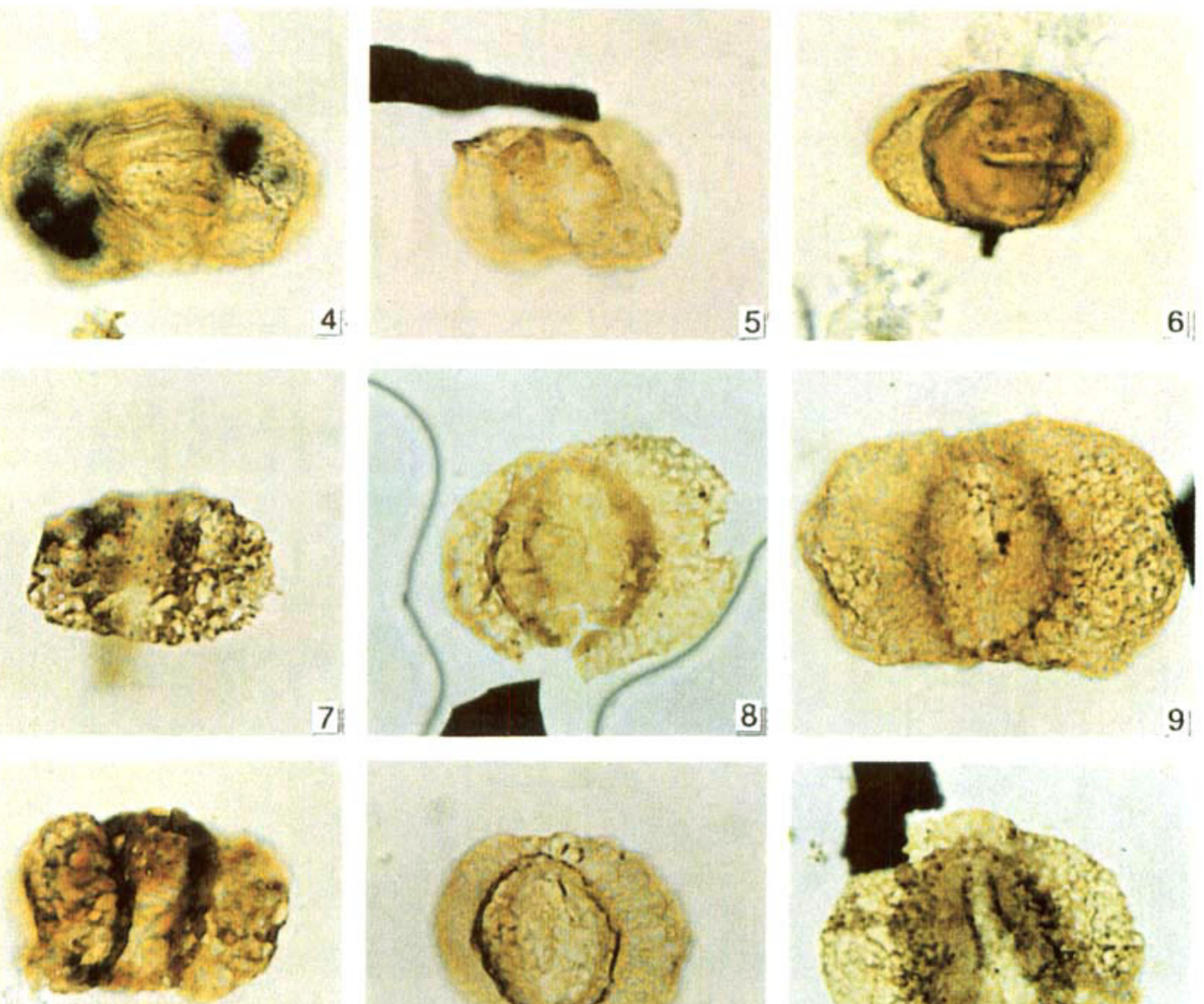

10
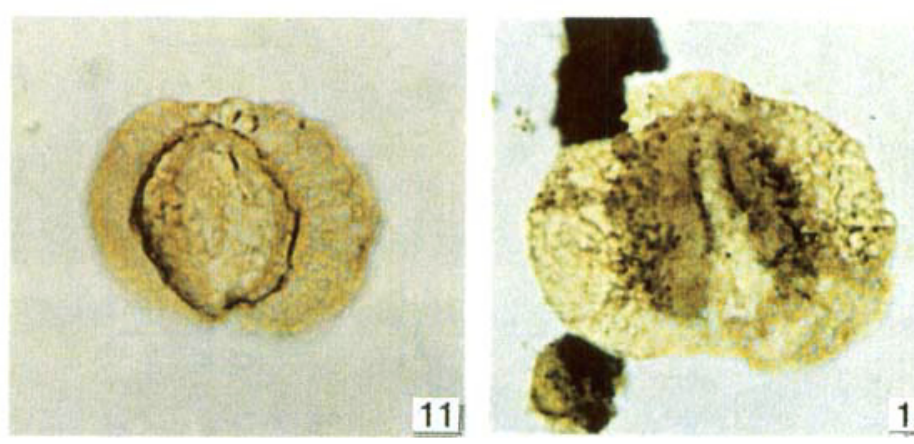

12 


\section{KAPP STAROSTIN FORMATION}
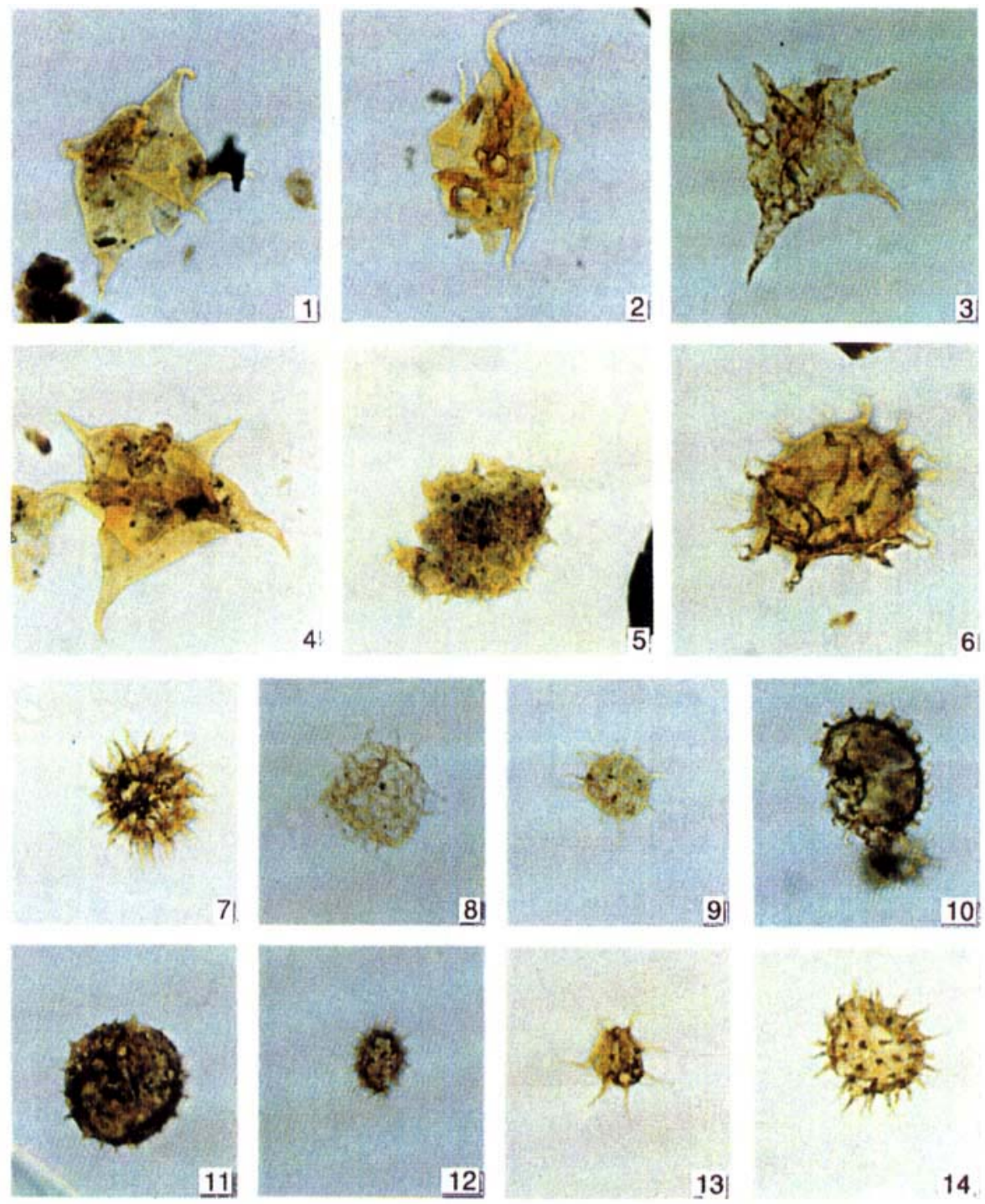

Reworked:
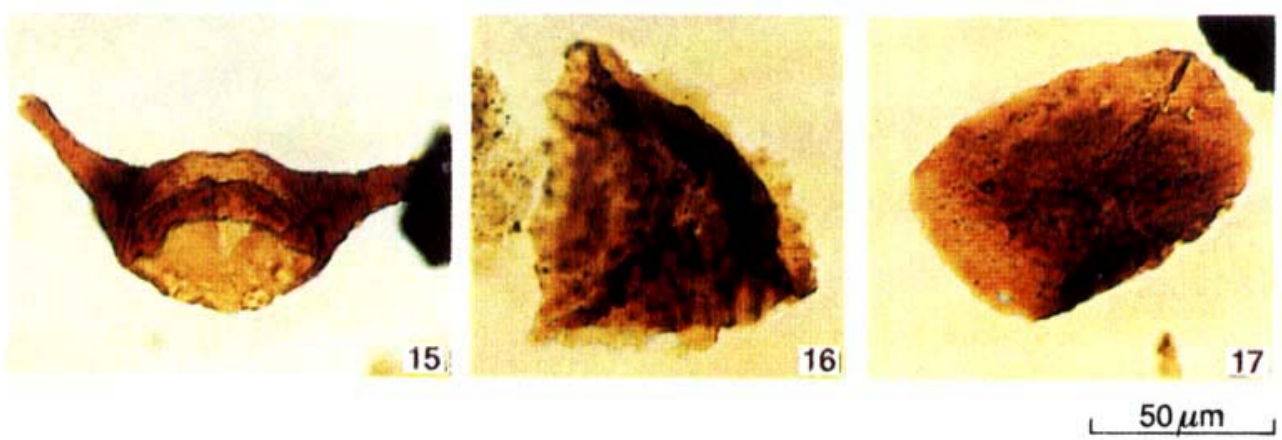


\section{References}

Balme, B. E. 1980: Palynology of Permian-Triassic boundary beds at Kap Stosch, East Greenland. Medd. Gronl. 200 (6). $37 \mathrm{pp}$.

Clayton, C., Coquel, R., Doubinger, J., Gueinn, K. J., Loboziak, S., Owens, B. \& Streel, M. 1977: Carboniferous miospores of western Europe: Illustrations and zonation. Meded. Rijks Geol. Dienst. 29, 1-71.

Cutbill, J. L. \& Challinor, A. 1965: Revision of the stratigraphical scheme for the Carboniferous and Permian rocks of Spitsbergen and Bjørnøya. Geol. Mag. 102, 418-439.

Czarniecki, S. 1969: Sedimentary environment and stratigraphical position of the Treskelodden Beds (Vestspitsbergen), Polska Akad. Nauk, Prace Muzeum Ziemi 16, 201-336.

Dons, C. E. 1983: Fasies og paleostromanalyse av Nordenskiöldbreen formasjonen (averkarbon-underperm), sentral Spitsbergen. [Facies and paleo current analysis of the Nordenskiöldbreen Formation (Late Carboniferous-early Permian), Central Spitsbergen]. Unpublished thesis (in Norwegian). University of Oslo. 344 pp.

Doré, A. G. 1991: The structural foundation and evolution of Mesozoic seaways between Europe and the Arctic. Palaeogeogr. Palaeoclimatol. Palaeoecol. 87, 441-492.

Dyupina, G. V. 1987: K metodike detal'nogo raschleneniya i korrelyatsii razrezov po palinologischeskim dannyn. [ A method for detailed subdivision and correlation of sections based on palynological data]. Pp. 85-100 in Biostratigrafiya i litologiya verkhnego paleozoya urala. [Upper Palacozoic Biostratigraphy and Lithology of the Ural Mountains]. Akad Nauk SSSR, Sverdlovsk.

Ezaki, Y. \& Kawamura, T. 1992: Carboniferous-Permian corals from Skansen and Festningen, Central Spitsbergen: their faunal characteristics. Pp. 59-77 in Nakamura K. (ed.): Investigations on the Upper Carboniferous-Upper Permian Succession of West Spitsbergen, Hokkaido University.

Federowski, J. 1967: The Lower Permian Tetracoralla and Tabulata from Treskelodden, Vestspitsbergen. Norsk Polarinst. Skr. 142, 11-44.

Federowski, J. 1986: The rugose coral faunas of the Carboniferous/Permian boundary interval. Acta Palaeont. Polonica 31, 253-276.

Fig. 17. Selected acritarchs and representative reworked spores from the Kapp Starostin Formation. Each figured palynomorph is located by abbreviated section name, sample level, PMO number and slide coordinates to an England Finder. Scale is added.

1. Unellium sp. KWI-3, $187 \mathrm{~m}$, PMO 139.086 , E54/2

2. Unellium sp. KWI-3, $187 \mathrm{~m}$, PMO $139.086, \mathrm{D} 53 / 4$

3. Unellium sp. KWI-3, 187 m, PMO 139.086, E46/2

4. Unellium sp. KWI-3, 187 m, PMO 139.086, J40/3

5-14 are all Micrhystridiums from sample KWI-3, $187 \mathrm{~m}$, PMO 139.086

15. Cornispora varicornata (reworked) KWI-5, $88 \mathrm{~m}$, PMO 139.088, A49/1

16. ?Gondispora sp. (reworked) KWI-5, $88 \mathrm{~m}$, PMO 139.088, G51

17. ?Gondispora sp. (reworked) KWI-5, $88 \mathrm{~m}$, PMO 139.088, D59/1
Gobbett, D. J. 1963: Carboniferous and Permian brachiopods of Svalbard. Norsk Polarinst. Skr. 127. 201 pp.

Harland, W. B., Armstrong, R. L., Cox, A. V., Craig, L. E., Smith, A. G. \& Smith, D. G. 1989: A geologic time scale. Cambridge University Press. $263 \mathrm{pp}$.

Hellem, T. A. 1980: En sedimentologisk og diagenetisk undersøkelse av utvalgte profiler fra Tempelfjorden gruppen (Perm) i Isfjorden området, Spitsbergen. [Sedimentology and diagenesis of selected profiles of the Tempelfjorden Group (Permian) in the Isfjorden area, Spitsbergen]. Unpublished thesis (in Norwegian). University of Oslo. $208 \mathrm{pp}$.

Hochuli, P. A., Colin, J. P. \& Vigran, J. O. 1989: Triassic biostratigraphy of the Barents Sea area. Pp. 131-153 in Collinson, J. D. (ed.): Correlation in Hydrocarbon Exploration. Norwegian Petroleum Society, Graham \& Trotman.

Igo, H. \& Okimura, Y. 1992: Carboniferous-Permian foraminifers of west Spitsbergen. Pp. 97-119 in Nakamura, K. (ed.): Investigations on the Upper Carboniferous-Upper Permian Succession of West Spitsbergen. Hokkaido University.

Keilen, H. B. 1992: Lower Permian sedimentary sequences in Central Spitsbergen, Svalbard. Pp. 127-139 in Nakamura, K. (ed.): Investigations on the Upper Carboniferous-Upper Permian Succession of West Spitsbergen. Hokkaido University.

Korchinskaya, M. V. 1986: Biostratigrafiya indskogo yarusa Shpitsbergena. [Biostratigraphy of the Induan stage of Spitsbergen (Svalbard)]. Pp. 77-93 in Krasil'shchikov, A. A. \& Miraev, M. N. (eds.) Geologija osadocnogo cechla archipelaga Spicbergen, Sbornik naucnych trudov. [Geology of the sedimentary blanket of the Archipelago of Svalbard]. Collection of Scientific Papers. Leningrad.

Mangerud, G. \& Konieczny, R. M. 1991: Palynological investigations of Permian rocks from Nordaustlandet, Svalbard. Polar Res. 9 (2), 155-167.

Molin, V. A. \& Koloda, N. A. 1972: Verkhnepermiskie sporovo-py'ssevye kompleksy severa Russkoi platformy. [Upper Permian spore and pollen complexes in the northern Russian platform]. Akad. Nauk SSSR, "Nauka", Leningrad. 76 pp.

Morozova, I. P. \& Kruchinina, O. N. 1986: Permskie mshanki arktiki (zapadnyi sektor) [The Permian bryozoans of the Arctic Region (Western Sector)]. Akad. Nauk SSSR, Moscow. 144 pp.

Mørk, A., Embry, A. F. \& Weitschat, W. 1989: Triassic transgressive-regression cycles in the Sverdrup Basin, Svalbard and the Barents Shelf. Pp. 113-130 in Collinson, J. D. (ed.): Correlation in Hydrocarbon Exploration. Norwegian Petroleum Society, Graham \& Trotman.

Nakamura, K., Kimura, G. \& Winsnes, T. S. 1987: Brachiopod zonation and age of the Permian Kapp Starostin Formation (Central Spitsbergen). Polar Res. 5, 207-219.

Nakamura, K., Tazawa, J. \& Kumon, F. 1992: Permian brachiopods of the Kapp Starostin Formation, west Spitsbergen. Pp. 77-97 in Nakamura, K. (ed.): Investigations on the Upper Carboniferous-Upper Permian Succession of West Spitsbergen. Hokkaido University.

Nakrem, H. A. 1991a: Conodonts from the Permian succession of Bjørnøya (Svalbard). Norsk. Geol. Tidsskr. 71, 235-248.

Nakrem, H. A. 1991b: Distribution of bryozoans in the Permian succession of Svalbard (preliminary data). Pp. 291-298 in Bigey, F. P. \& d'Hondt, J. L. (eds.): Bryzoaires actuels et Fossiles (Bryozoa Living and Fossil): Bulletin l'Ouest de la France, Mémoire HS I. Nantes, France.

Nakrem, H. A., Nilsson, I. \& Mangerud, G. 1992: Permian Biostratigraphy of Svalbard (Arctic Norway) - A Review. International Geology Review 34 (9), 933-959. 
Nassichuk, W. W. \& Wilde, G. L. 1977: Permian fusulinaceans and stratigraphy at Blind Fiord, Southwestern Ellesmere Island. Geol. Surv. Can. Bull. 268, 1-59.

Nilsson, I. 1988: Carboniferous and Permian fusulinids from the Nordfjorden Block, Spitsbergen (Svalbard). Unpublished thesis, University of Oslo. $159 \mathrm{pp}$.

Piasecki, S. 1984: Preliminary palynostratigraphy of the Permian-Lower Triassic sediments in Jameson Land and Scoresby Land, East Greenland. Bull. Geol. Soc. Denmark 32, 139 144.

Playford, G. 1962a: Lower Carboniferous microfloras of Spitsbergen. Part 1. Palaeontology 5 (3), 550-618.

Playford, G. 1962b: Lower Carboniferous microfloras of Spitsbergen. Part 2. Palaeontology 5 (4), 619-678.

Sakagami, S. 1992: Notes on the Permian bryozoans from the Kapp Starostin Formation at Festningen route, Spitsbergen. Pp. 39-59 in Nakamura, K. (ed.): Investigations on the Upper Carboniferous-Upper Permian Succession of West Spitsbergen. Hokkaido University.

Skaug, M. 1982: Bentiske fossile assosiasjoner og faciesvariasjoner i Nordenskiöldbreen formasjonen (overkarbonunderperm), sentrale Spitsbergen. [Benthic fossil associations and facies variation in the Nordenskiöldbreen Formation (Late Carboniferous-Early Permian), Central Spitsbergen]. Unpublished thesis (in Norwegian), University of Oslo. 220 pp.

Sosipatrova, G. P. 1967: Upper Palaeozoic Foraminifera of Spitsbergen. Pp. 125-165 in Sokolov, V. N. (ed.): Stratigraphy of Spitsbergen. British Library, Lending Division, Boston Spa.

Steel, R. J. \& Worsley, D. 1984: Svalbard's post-Caledonian strata. An atlas of sedimentational patterns and palaeogeographic evolution. Pp. 109-135 in Spencer, A. M. et al. (eds.): Petroleum Geology of the North European Margin. Norwegian Petroleum Society, Graham \& Trotman, London. Stemmerik, L. 1988: Discussion. Brachiopod zonation and age of the Permian Kapp Starostin Formation (Central Spitsbergen). Polar Res. 6, 179-180.

Szaniawski, H. \& Malkowski, K. 1979: Conodonts from the Kapp Starostin Formation (Permian) of Spitsbergen. Acta Palaeontol. Pol. 24 (2), 231-264.

Tozer, E. T. \& Parker, J. R. 1968: Notes on the Triassic biostratigraphy of Svalbard. Geol. Mag. 105 (6), 526-542.

Ustritskii, V. I. 1967: Main features of the stratigraphy and palaeogeography of the Upper Palaeozoic of Spitsbergen. Pp. 98-124 in Sokolov, V. N. (ed.): Stratigraphy of Spitsbergen, British Library, Lending Division, Boston Spa.

Ustritskii, V. I. 1979: O Raspredezenii brakhopod v verkhnepermskikh otlozheniyakh Shpitsbergena. [Distribution of brachiopods in the Upper Permian sediments of Spitsbergen]. Pp. 126-133 in Verkhnyy paleozoyi mezozoy ostrovov i poberezhya arkticheskikh mure USSR, [The Upper Palcozoic and Mesozoic of the islands and Coastlands of the Arctic Seas of the USSR]. Leningrad.

Utting, J. 1985: Preliminary results of palynological studies of the Permian and lowermost Triassic sediments, Sabine Peninsula, Melville Island, Canadian Arctic Archipelago. Current Research B, Geol. Surv. Can. Pap. 85-1B, 231-238.

Utting, J. 1989: Preliminary palynological zonation of surface and subsurface sections of Carboniferous, Permian and lowest Triassic rocks, Sverdrup Basin, Canadian Arctic Archipelago. Current Research, Geol. Surv. Can., Pap. 89-1G, 233-240.

Varyukhina, L. M. 1971: Spory $i$ pyl'tsa krasnotsvetnykh $i$ uglenosnykh otlozhenii permi $i$ triasa severo-vostoka europeiskoi chasti SSSR. [The spores and pollen of red-coloured and Carboniferous deposits of the Permian and Triassic in the North-East European part of Russia]. Leningrad. 159 pp. Akad. Nauk. SSSR, "Nauka".

Varyukhina, L. M. 1980: Kharakteristike ufimskikh otlozheniuy pechorsky sineklizy). [A palynologic characterization of the Ufimian deposits of the Pechora syneclise]. Acad. Sci. USSR Komi. Branch. Inst. Geol., Trans. 33, 59-66.

\section{Appendix}

Maps showing the localisation of the 16 different Permian sections and composite sections sampled for this study. The sections are arranged in the same order as in Fig. 1 (see Loc. number). 


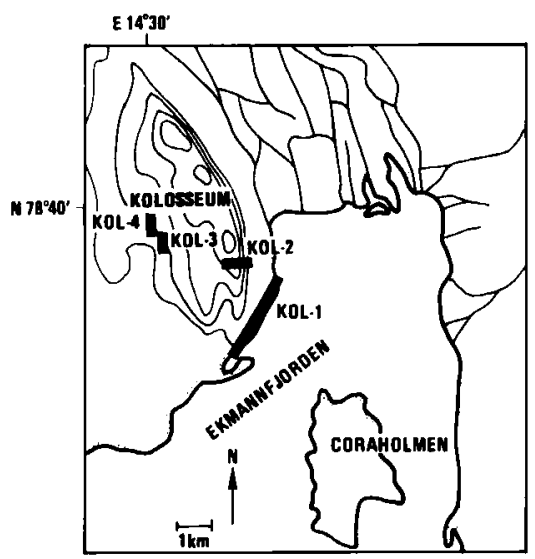

Loc. 1
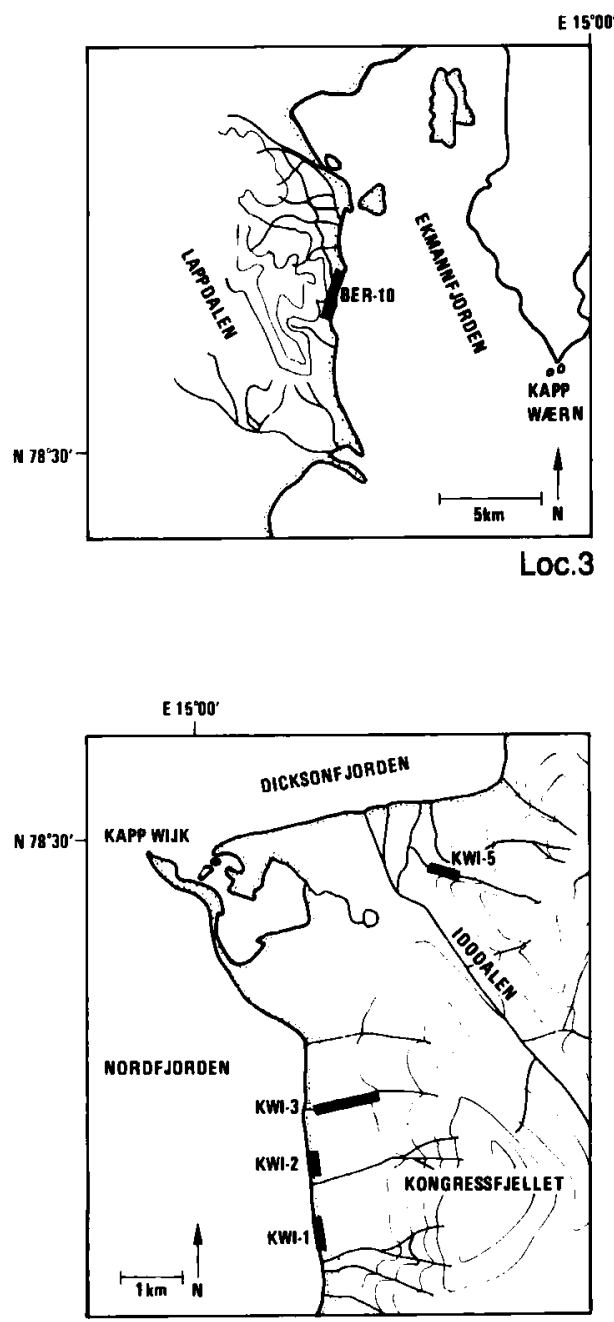

Loc.5

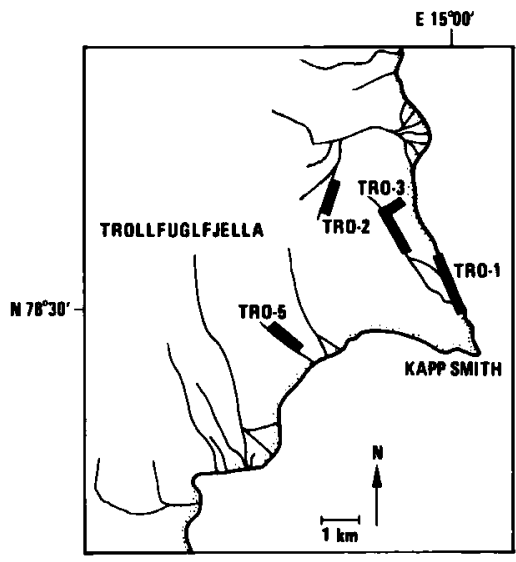

Loc.2
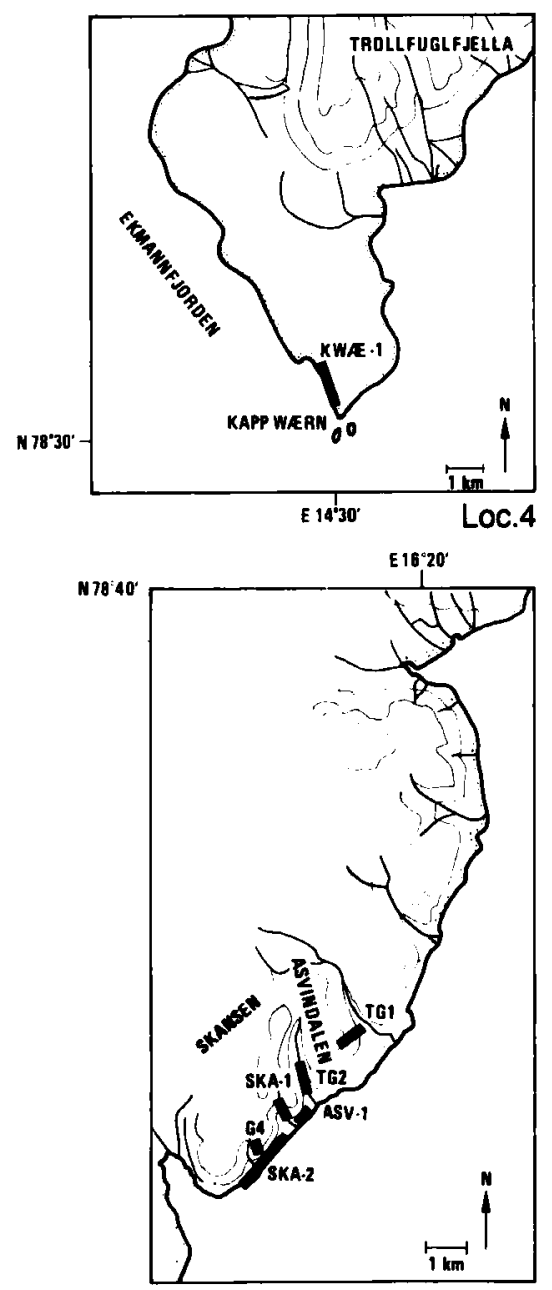

Loc.6 


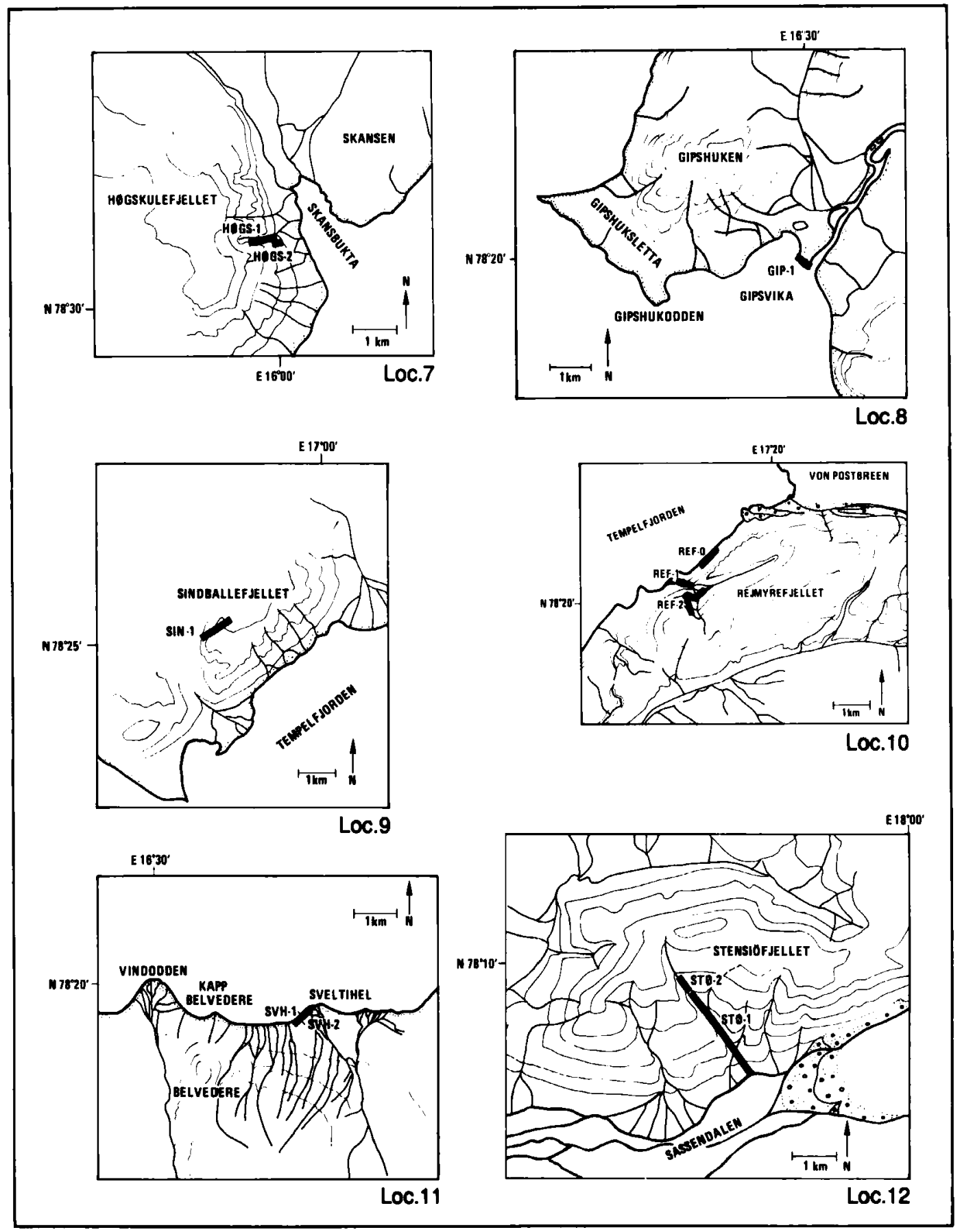




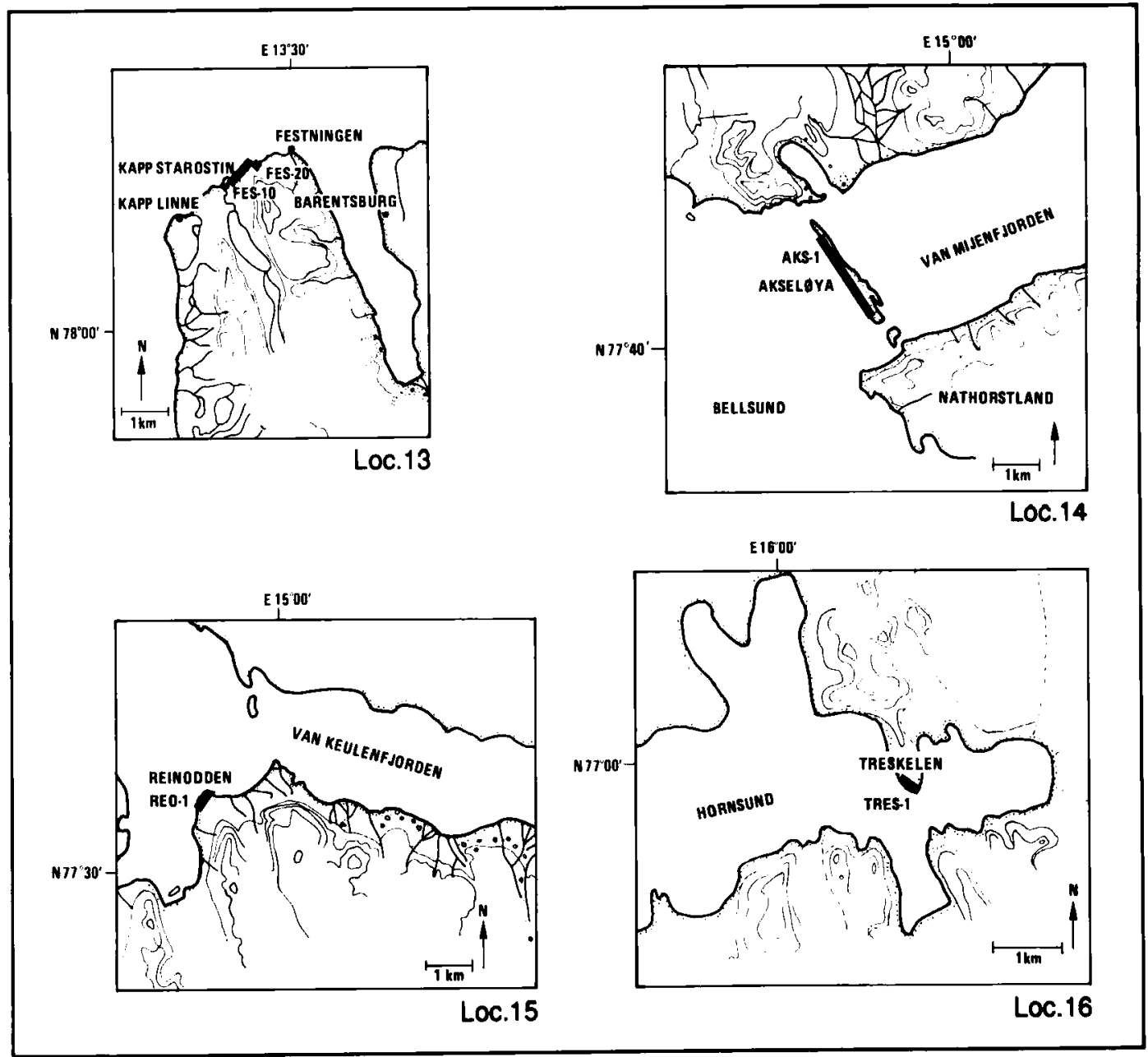

